\title{
Thermal impact of dykes on ignimbrite and implications for fluid flow compartmentalisation in calderas
}

\author{
Ben M. Kennedy ${ }^{\star \alpha}$, Michael J. Heap ${ }^{\beta, \gamma}$, Steffi Burchardt ${ }^{\delta}$, Marlène Villeneuve ${ }^{\epsilon}$, Hugh Tuffen ${ }^{\zeta}$, \\ H. Albert Gilg $\eta$, Jonathan Davidson ${ }^{\alpha}$, Neryda Duncan $^{\theta, \iota}$, Elodie Saubin ${ }^{\alpha}$, \\ Einar Bessi Gestsson ${ }^{\kappa}$, Marzieh Anjomrouz ${ }^{\theta}$, Philip Butler ${ }^{\theta, \iota}$ \\ ${ }^{\alpha}$ School of Earth and the Environment, University of Canterbury, Christchurch, New Zealand. \\ $\beta$ Université de Strasbourg, CNRS, Institut Terre et Environnement de Strasbourg, UMR 7063, \\ 5 rue René Descartes, Strasbourg 67084, France.

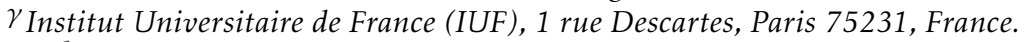 \\ ${ }^{\delta}$ Department of Earth Sciences, Uppsala University, Uppsala, Sweden. \\ ${ }^{\epsilon}$ Subsurface Engineering, Montanuniversität Leoben, A-8700 Leoben, Franz-Josef-Strasse 18, Austria.

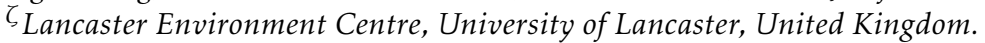 \\ $\eta^{\prime}$ Engineering Geology, Department of Civil and Environmental Engineering, TUM School of Engineering and Design, \\ Arcisstr. 21, 80333 Munich, Germany. \\ ${ }^{\theta}$ MARS Bioimaging Ltd, Christchurch, New Zealand. \\ 'School of Physical and Chemical Sciences, University of Canterbury, Christchurch, New Zealand. \\ ${ }^{\kappa}$ Icelandic Meteorological Office, Reykjavik, Iceland.
}

\begin{abstract}
Ignimbrites within calderas host intrusions with hazardous and/or economically significant hydrothermal systems. The Hvítserkur ignimbrite at Breiðavík caldera, north-eastern Iceland, is intruded by basaltic dykes. The country rock ignimbrite is generally soft and zeolite-rich, has low permeability, high porosity, and few macrofractures. However, the ignimbrite immediately adjacent to the dyke is hard, recrystallised quartz, plagioclase, and alkali feldspar, with a low permeability and porosity and frequent macrofractures. At 1-2 m from the dyke, the ignimbrite is hard, dominantly glassy with pervasive perlitic microfractures, has high permeability, but low porosity and frequent macrofractures. A narrow zone of pervasive unlithified clay exists $2 \mathrm{~m}$ from the dyke. The dyke intrusion promoted a narrow zone of welding, fracturing, and perlitisation in the ignimbrite resulting in high permeability and focussed alteration. Our study shows how intrusions and their thermal aureoles create vertical pathways for, and horizontal barriers to, geothermal fluid flow.
\end{abstract}

Keywords: Caldera; Volcano; Alteration; Hydrothermal; Permeability

\section{InTRODUCTION}

Dykes and hydrothermal systems within porous volcanic rocks represent a hazard related to hydrothermal explosions [e.g. Hedenquist and Henley 1985; Bixley and Browne 1988; Barberi et al. 1992; Bromley and Mongillo 1994; Browne and Lawless 2001; Montanaro et al. 2020; 2021] and a geothermal resource [e.g. Bibby et al. 1995; Bertrand et al. 2012; Rowland and Simmons 2012; McNamara et al. 2016; Heap et al. 2020a; Spittler et al. 2020]. In these systems, the fluid composition [Garden et al. 2020], matrix permeability [Saar and Manga 1999; Heap et al. 2017a; Kushnir et al. 2018; Mordensky et al. 2018b; Cavazos-Álvarez et al. 2020], and fracture pathways [Rissmann et al. 2011; Heap and Kennedy 2016; Garden et al. 2017; Mordensky et al. 2018a; Kennedy et al. 2020] within the volcanic rock determine the type of hazard, as well as the resource potential. However, barriers to fluid flow, such as faults

*Corresponding author: ben.kennedy@canterbury.ac.nz and sheet intrusions, may also channelise or compartmentalise flow [Bruhn et al. 1990; Caine et al. 1996; Evans et al. 1997; Caine and Forster 1999; Chevallier and Woodford 1999; Cello et al. 2001; Quinao et al. 2013]. Channelisation and barriers to fluid flow can generate locally raised pore pressures that are sufficient to promote volcanic hazards. Possible hazards include slope failure [e.g. Day 1996; Heap et al. 2021a; b], hydrothermal eruptions [Fitzgerald et al. 2014; Mayer et al. 2015; Kennedy et al. 2020], and erratic explosive behaviour [Heap et al. 2019]. Resources may be geothermal, mineralogical, hydrological, or petroleum-based [Bischoff et al. 2019]. However, volcanic rocks are notoriously variable; and even within a single type of volcanic rock, e.g. ignimbrites, there is huge variability in physical and mechanical properties [Sruoga et al. 2004; Pola et al. 2012; Wyering et al. 2014; Heap et al. 2020b; Heap and Violay 2021], and so fluid flow is difficult to model. As a consequence, the related hazards and resource potential are difficult to predict. 
Compartmentalisation occurs when fluid flow is restricted to a particular area within the stratigraphy, bounded by fluid flow barriers. It is observed in aquifers, petroleum reservoirs, geothermal fields [e.g. Quinao et al. 2013; Rateau et al. 2013; McNamara et al. 2016; Senger et al. 2017], and hydrothermal systems at volcanoes [e.g. Hurwitz 2003; Delcamp et al. 2016; Ball et al. 2018; Finn et al. 2018]; and can be driven by mineral precipitation associated with chemical [Farquharson et al. 2019], barometric, or thermal gradients or structural discontinuities such as faults and shear zones [e.g. Watson et al. 2007; Árnason 2020]. Dykes are common features in volcanic environments, and dyke intrusion enhances the barometric, chemical, thermal, and structural discontinuity gradients within the volcanic host rock [Senger et al. 2017]. The composition, temperature, width, and dynamic history of the dyke determines its impact on the properties of the surrounding rocks [e.g. Kennedy et al. 2010; Schauroth et al. 2016; Annen 2017].

The physical and thermal properties and stratigraphic architecture of the host volcanic rock(s) influence how the dyke intrudes (i.e. initiation, propagation, and arrest), which in turn affects compartmentalisation and fluid flow [e.g. Kavanagh et al. 2006; Burchardt 2008; Taisne and Jaupart 2009; Burchardt et al. 2011; Maccaferri et al. 2011; Taisne et al. 2011; Krumbholz et al. 2014]. The intrusion of the dyke additionally influences and is influenced by the tectonic and volcanic stress field and the structure of the volcanic plumbing system [Gudmundsson 2002; Galland et al. 2014].

Most calderas have all the components to host hydrothermal systems [Stix et al. 2003]: a thick accumulation of ignimbrite within the caldera, the presence of faults related to both subsidence and uplift, and a history of intrusion by complex shallow plumbing systems [Kennedy et al. 2018]. Field examples show how intra-caldera dykes affect fracture orientation and density [Garden et al. 2017], and ignimbrites record a huge variation in matrix physical properties [Sruoga et al. 2004; Heap et al. 2020a]. Several authors have attempted to combine field and laboratory measurements to make inferences on the changes in physical properties of the rock matrix and mass surrounding intrusions, and these are frequently complicated by local variations in primary volcanic texture [Mordensky et al. 2018a; b; Saubin et al. 2019]. To date, and to the authors' knowledge, there has been no systematic study that links the fracture patterns and the physical properties within dyke-modified caldera-filling ignimbrite. Such a study could provide a spatially and lithologically constrained model of the dyke-driven compartmentalisation of fluid flow.

Here, we capitalise on the exceptional exposure of the eroded Breiðuvík caldera in the northernmost East Fjords of Iceland. The Neogene age (23.03-2.58 Ma) Breiðuvík caldera is located within a large volcanic cluster in the northernmost part of the East Fjords of
Iceland [Figure 1; Burchardt et al. 2011; Berg et al. 2018; Burchardt et al. 2021]. Within the volcanic cluster, effusive and explosive eruptions produced large volumes of rhyolite as lava flows and ignimbrites. The latter occur as voluminous caldera infill, such as at Hvítserkur, as well as sheets that covered the landscape at the time. Rhyolitic volcanic activity in the area was accompanied by voluminous olivine basalt magmatism, as seen in geological maps of the northern half of eastern Iceland [Óskarsson and Riishuus 2013].

The Breiðuvík caldera formed at $12.41 \pm 0.28 \mathrm{Ma}$ [Berg et al. 2018] and was associated with the deposition of a partly-welded, rhyolitic ignimbrite filling a bowl-shaped depression. The maximum exposed thickness of the ignimbrite within the caldera is up to $400 \mathrm{~m}$. The mountains Hvítserkur and Leirfjall expose complete sections through the ignimbrite, as well as the underlying basaltic lavas. The ignimbrite is overlain by 2 to $70 \mathrm{~m}$-thick lake sediments that most likely originate from the erosion and deposition of the ignimbrite outside the caldera. High whole-rock $\delta^{18} \mathrm{O}$ values indicate that the ignimbrite was subsequently altered in a hot spring environment in the caldera lake [Berg et al. 2018]. Olivine basalt magma intruded the Hvítserkur ignimbrite and the overlying sediments in the form of dykes and sills and fed eruptions in the caldera lake. The resulting hyaloclastite breccias and pillow lavas overlay the Hvítserkur ignimbrite and 2-3 $\mathrm{m}$ of lake sediments at the top of the mountain.

The iconic southern flank of Hvítserkur superbly exposes the complex network of basaltic dykes that crosscut the unwelded ignimbrite (Figure 1A). Since some of the dykes can be seen to connect to vents and pillow breccias that were erupted into the caldera lake, we can constrain the depth of intrusion of the dykes to $0-300 \mathrm{~m}$ in the southern flank of Hvitserkur. Using mineral geothermometry on plagioclase in some of the dykes in the Hvítserkur ignimbrite, Gestsson [2018] determined the magma temperature to be approximately $1130^{\circ} \mathrm{C}$, which had a pronounced effect on the ignimbrite in contact with the intrusions. Preferential erosion of many dyke interiors has generated morphological channels, while the adjacent thermally altered ignimbrite stands out as metre-high walls that flank the dykes and stand proud of the unaltered far-field ignimbrite (Figure 1B).

Our aims are to: (1) use geotechnical techniques to characterise the impact of dyke intrusion on a) matrix and b) effective fracture permeability; (2) compare the textural characteristics and mineralogy of samples within the thermal aureole, and (3) explore implications for subsurface fluid flow within ignimbrite-filled calderas. 

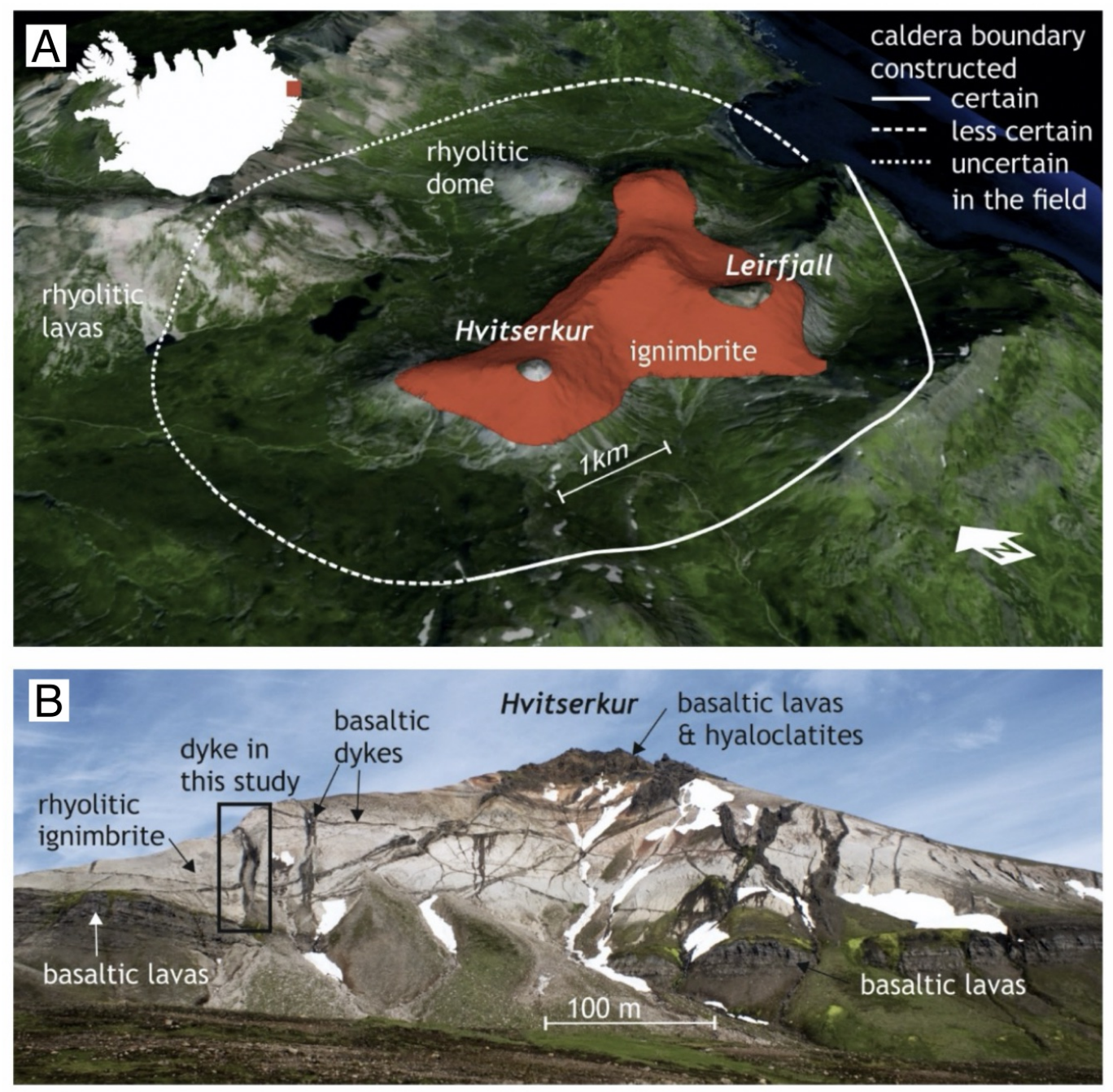

Figure 1: [A] Location map showing the studied field area (mountains Hvítserkur and Leirfjall; East Iceland). The ignimbrite is shown in red. [B] Photograph of Hvítserkur taken looking North illustrating the location of the studied dyke and the relationship to the other dykes, and the ignimbrite.

\section{Methods}

We systematically measured rock properties in the field and in the laboratory. In the field we surveyed Hvitserkur mountain using a DJI Phantom 3 drone taking oblique photos roughly parallel to the ground surface ( $\sim 20$ to 45 degrees to the horizontal) at approximately $30 \mathrm{~m}$ above ground every $\sim 20 \mathrm{~m}$. This photo mosaic allowed us to create a Structure-from-Motion digital surface model with a resolution on the order of $1-5 \mathrm{~cm}$ using the software Agisoft Metashape Pro. From this survey, we selected the optimal locations-based on accessibility and continuous exposure-for sampling, scanline mapping, and Schmidt hammer data collection.

The field location for detailed sampling was a transect on the western side of a 6 m-wide basaltic dyke (the eastern side was not investigated in detail). The steep and loose terrain meant the transect was divided in two parts to avoid areas of loose rock. When combined, this formed a single continuous scanline ap- proximately perpendicular to the dyke margin (Figure $2 \mathrm{~B}$ ). Along this scanline we were able to provide a dense array of field strength estimates, collected using a Schmidt rebound hammer. Measurements were made with a type-L Schmidt hammer held perpendicular to the rock surface, following the method defined by Torabi et al. [2010]. The Schmidt hammer releases a spring-driven piston onto the outcrop; the piston rebound can be read directly by the user. Relatively hard surfaces yield higher rebound distances than softer surfaces, and this value has been shown to correlate with the strength [e.g. Deere and Miller 1966; del Potro and Hürlimann 2008; Kılıç and Teymen 2008; Harnett et al. 2019] and Young's modulus [e.g. Dinçer et al. 2004] of the rock. The relative ease of use of the Schmidt hammer allowed for a high concentration of measurements, from which we used the ten highest measurements every $10 \mathrm{~cm}$. The locations of single impacts were separated by at least the piston diameter, to avoid inducing damage in sites of subsequent measurement. 
Along the same transect we used a scanline to map discontinuity characteristics, discontinuity type, dip magnitude and dip direction, frequency, endpoint visibility, number of visible endpoints, termination type, strike, aperture, rock type, trace length, exposure area, and texture, infill, staining, and seepage, consistent with other volcanic studies [e.g. Moon et al. 2005; Garden et al. 2017; Mordensky et al. 2018b; Saubin et al. 2019].

We collected five $\sim 10 \mathrm{~kg}$ blocks of ignimbrite at systematic distances from the dyke margin and drilled them to produce $20 \mathrm{~mm}$-diameter cylindrical cores, $40 \mathrm{~mm}$ in length, suitable for physical property characterisation in the laboratory (inset in Figure 2). Samples avoided macrofractures and were oriented in the field, although the steep terrain made this challenging. Samples were cored in two orthogonal directions (approximately parallel and perpendicular to the dyke margin) to investigate whether permeability is anisotropic. The samples were first washed with water and dried in a vacuum-oven $\left(\right.$ at $40^{\circ} \mathrm{C}$ ) for at least 48 hours. A helium pycnometer determined the connected skeletal volume of the samples, and the connected porosities were calculated using the bulk sample volume (determined using the sample dimensions). Total porosities were calculated using the bulk sample density (determined using the sample mass and dimensions) and the solid density (determined using the mass and volume of a powdered sample, the latter measured using the helium pycnometer). We measured matrix permeability using a nitrogen benchtop gas permeameter at the University of Strasbourg in France [Heap and Kennedy 2016] under a confining pressure of $1 \mathrm{MPa}$. Prior to measurements of permeability, the samples were left at $1 \mathrm{MPa}$ for 1 hour to allow for microstructural equilibration. Due to the low permeability of these samples, we used the pulse-decay method [Brace et al. 1968]. We checked for whether the Forchheimer [Forchheimer 1901] or Klinkenberg [Klinkenberg 1941] corrections were necessary, and applied them on a case-by-case basis (all but one of the measured samples required a Klinkenberg correction; no samples required a Forchheimer correction). Details of these corrections can be found in Heap et al. [2017b]. The experimental error on the measurements of porosity and permeability are $\ll 1 \%$ and $<1 \%$, respectively.

Mineralogical composition and textures were analysed using a combination of thin section microscopy and X-ray powder diffraction (XRPD) analysis using materials taken from the same blocks. Thin sections were prepared to dimensions of $25 \times 47 \mathrm{~mm}$, ground to $30 \mu \mathrm{m}$ thickness, and mounted without cover slips. Preliminary thin section analysis using a polarising light petrographic microscope allowed phenocryst phases to be identified and further textural analysis was carried out using a JEOL-IT300 Scanning Electron Microscope (SEM) at the University of Canterbury in New Zealand.
Table 1: Geological sample scanning protocol parameters

\begin{aligned} \hline Parameter & Protocol \\ \hline Voltage & $120 \mathrm{kVp} \\$ Current & 28 \\ Exposure Time & 250 \\ Filter & $1.96 \mathrm{~mm} \mathrm{Al} \\$ Reconstructed Voxel Size & $0.05 \mathrm{~mm}^{3} \\$ Energy Thresholds & $15,35,55,75 \mathrm{keV} \\$ Projections & $720 \mathrm{pr} /$ rotation \\ Magnification & 1.26 \\ Pixel Size & $0.11 \mathrm{~mm} \\$ Resolution & $150 \mu \mathrm{m} \\$\hline & \end{aligned}

To analyse for any 3D alignment of pumices and lithic clasts, the samples were scanned in a MARS spectral X-ray computed tomography (CT) scanner, which utilises photon-counting, energy resolving Medipix3RX detector chips. This detector technology has a small pixel size, $110 \times 110 \mu \mathrm{m}$, and in parallel with an X-ray source focal spot size of $70 \mu \mathrm{m}$ can provide a sufficient spatial resolution [De Ruiter 2015; Panta 2015; Anjomrouz 2017]. The reconstructed voxel size of these MARS scans is $50 \mu \mathrm{m}$, therefore structures of this size within a sample are able to be resolved. The parameters that were selected for an optimised scanning protocol for geological samples are outlined in Table 1. The scan data were processed using MATLAB and visualised using MARS Vision [Duncan 2021].

Sample aliquots were ground for XRPD analysis using a McCrone micronizing mill with agate cylinder elements in isopropanol. Zinc oxide (10 wt.\%) was added as an internal standard to quantify amorphous phases. Side-loaded powder mounts were analysed using a Bruker D8 Advance Eco diffractometer (goniometer radius $250 \mathrm{~mm}$ ) with $\mathrm{CuK} \alpha$ radiation $(40 \mathrm{kV}, 25 \mathrm{~mA}$; automatic divergent slit, primary and secondary sollers of $2.5^{\circ}$ opening) from 2 to $75^{\circ} 2 \theta$ using a 1-D Lynxeye XE-T detector. Mineral quantification was carried using the Rietveld program BGMN [Bergmann et al. 1998] and the PROFEX graphical user interface [Doebelin and Kleeberg 2015].

\section{Results}

The "country rock" beige ignimbrite is zeolite rich with prevalent light green colouration in pumice clasts and fractures with green alteration haloes. The ignimbrite exposed in the $200 \mathrm{~m}$ of vertical exposure on the Southfacing flank of Hvítserkur contains 30 dykes across a $530 \mathrm{~m}$ horizontal transect. We focus our investigations on a $6 \mathrm{~m}$-wide mafic dyke that is near vertical and strikes NNW-SSE. The digital surface model shows both dyke margins clearly expressed geomorphologically as two walls (2-3 m thick) of more resis- 
tant, black- to brown-coloured welded ignimbrite (Figure $2 \mathrm{~B}$ ). Immediately adjacent to the ignimbrite walls of the dyke, we detected a layer of brown-coloured, fine grained, unconsolidated clay-material forming a $20-40 \mathrm{~cm}$-thick sheet parallel to the ignimbrite walls, resembling chocolate pudding.

We completed a scanline measuring the orientation, number and type of fractures in the ignimbrite perpendicular to the dyke margin on the western side (Figure 3), which shows that, within the first $3 \mathrm{~m}$ of the dyke margin in the dark, perlitised, and blue ignimbrite, there are $2-4$ fractures per $25 \mathrm{~cm}$ interval. This fractured zone can be seen in Figure 2. The number of fractures per $25 \mathrm{~cm}$ interval drops to $0-2$ beyond $3 \mathrm{~m}$ from the dyke margin (Figure $3 \mathrm{~A}$ ). Close to the margin of the dyke, in the dark and perlitised ignimbrite, fractures (black and grey circles in Figure 3B) strike near parallel with, or perpendicular to, the $\sim$ NNW-SSEstriking dyke margin (green circle in Figure 3B) and are dominantly near-vertical, whereas the fractures strike dominantly NNE-SSW in the blue ignimbrite and ignimbrite further from the dyke (as shown in Figure 2 and the blue and yellow circles in Figure 3B), again dominantly near vertical. These fractures in the blue ignimbrite and ignimbrite further from the dyke are clearly seen in the drone image of the outcrop (Figure 2). The orientation of other dykes (red diamonds in Figure $3 \mathrm{~B}$ ) show that steeply dipping $\left(>70^{\circ}\right)$ dyke structures comprise nearly $75 \%$ of all measured dykes and strike NNE-SSW to NE-SW, while a minor set of shallow dipping sheet intrusions appears to be parallel to the base of the caldera depression (Figure 3B). These fractures in the blue ignimbrite and ignimbrite further from the dyke are clearly seen in the drone image of the outcrop (Figure 2).

Our Schmidt hammer transect across the rhyolitic ignimbrite away from the contact with the basalt shows that rebound values within the first $1.2 \mathrm{~m}$ of dark ignimbrite are mostly between 20-35 (Figure 4). Schmidt rebound values decrease to about 15 between 1.2 and $2 \mathrm{~m}$ from the dyke. At distances $>2 \mathrm{~m}$ from the dyke margin, the rebound values decrease further, to between 5 and 10 (Figure 4). The low number of data points beyond $2 \mathrm{~m}$ is due to the rock being too soft to register a rebound value on the Schmidt hammer (i.e. $<10)$. The vertical layer of unconsolidated chocolatebrown fine-grained clay with the texture of chocolate pudding was too soft to measure with the Schmidt hammer at a distance of about $2.8 \mathrm{~m}$.

The laboratory analyses were performed on samples prepared from blocks that were collected where possible from the outcrop. These blocks allowed us to characterise the mineralogy, textures and physical properties of the ignimbrite at various distances from the dyke margin to complement and inform the field results. The XRPD results (Table 2) show that the ignimbrite sample collected closest to the dyke $(45 \mathrm{~cm})$ has recrystallised at high temperature to quartz and feldspars, with no glass or zeolites present. Microstructurally, the sample shows ash-sized pumice fragments resembling fiamme (Figure 5A), characteristic of welded ignimbrites, but there is no sample scale orientation of the larger pumices visible on CT scans of any sample. For example, the sample of dark ignimbrite with welding textures is shown in Figure 6 and shows an absence of lapilli-sized pumice or lithic clast alignment. The SEM images (Figure 5A) reveal that the original pumice shapes have lost vesicularity and crystallised to form quartz and feldspar. Lithic clasts present show no alignment and contain higher percentages of mafic minerals. At a distance of $205 \mathrm{~cm}$ from the dyke, but still forming part of the dark wall or thermally altered, more erosion-resistant ignimbrite, the sample contains $52 \mathrm{wt} . \%$ glass. Potentially some of this glass could be opal-A/cristobalite. However, SEM analysis indicates that it looks like glass (Figure 5B), and some pumiceous textures and lithic clasts can be seen, but large parts of the sample are dominated by distinctive curved perlitic cracks (Figure 5B). Original pumiceous textures are difficult to distinguish, due to compaction and perlitic fracturing. Porosity is only present in the perlitic cracks and open cracks around larger clasts which, in some areas, have recrystallised locally forming silica polymorphs (Figure 5B).

Samples from distances of 305-705 $\mathrm{m}$ from the dyke margin have similar mineralogy and textures. They display a range of distinct clast colours representing lithic clasts and lapilli sized pumices with varying amounts of alteration and porosity. These samples predominantly comprise zeolites (37-49 wt.\%) and glass (2537 wt.\%). Glass shards show original bubble wall morphologies with no evidence of welding (Figure 5CE), and the interior of these larger shards/ash-sized pumice fragments frequently show vug-like zeolites that have grown into cavities. Such cavities are the dominant type of porosity and occur within the ash matrix, rather than the larger pumices. As a result, these samples are significantly more porous than the densely compacted samples closer to the dyke. In some areas, the zeolites have formed spheroidal recrystallisation cores to glass shards. Microfractures radiate from recrystallised pumice zeolite spheroids and crosscut the matrix but do not penetrate into the lithic clasts (Figure 5C).

The porosity and permeability data from the laboratory illustrate how the microstructures seen in the SEM can influence the physical properties of the ignimbrite. Figure 7A-B show laboratory-measured connected porosity and permeability as a function of distance from the dyke (data available in Table 3). Close to the dyke $(0.45 \mathrm{~m}$ from the margin, in the recrystalized dark ignimbrite), the porosity of the sample is very low (0.01-0.03) and permeability is too low to measure with our experimental set up $\left(<10^{-18} \mathrm{~m}^{2}\right)$, consistent with the lack of pores and microfractures seen in our microstructural analyses (Figure 5A). At $2.05 \mathrm{~m}$ from 

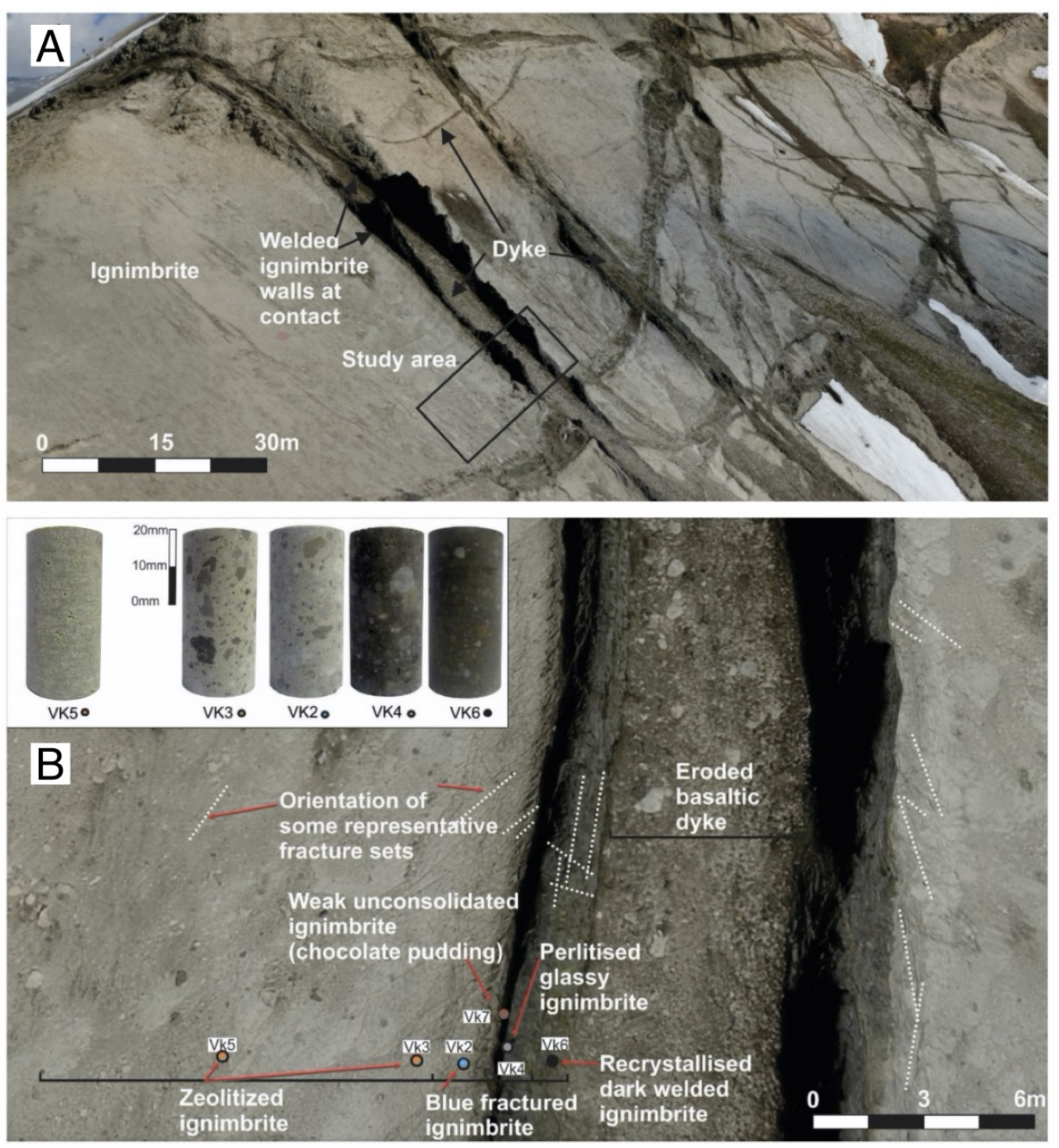

Figure 2: [A] Structure from motion photogrammetry reconstruction (orthophoto) of an oblique view (from the East) of the field site at Hvítserkur (East Iceland). [B] Study area with sample and scan line locations marked. Orientations of some fractures are highlighted by dotted white lines. Photographs of examples of the $20 \mathrm{~mm}$ diameter cylindrical samples prepared for the laboratory measurements (inset): VK5 and VK3 zeolitized ignimbrite samples, VK2 blue ignimbrite, VK4 perlitised ignimbrite, and VK6 dark ignimbrite.

the dyke margin, in the perlitised dark ignimbrite, the porosity is $\sim 0.07$ and the permeability increases, but is quite variable, from $\sim 4 \times 10^{-17}$ to $\sim 3 \times 10^{-16} \mathrm{~m}^{2}$. This permeability increase coincides with the occurrence of perlitic cracks seen in our microstructural analyses (Figure 5B). Additionally, the CT scans show a significant porosity around larger lithic clasts and dense pumice lapilli (Figure 6). Porosity increases to about 0.15 at a distance of $3.05 \mathrm{~m}$ from the dyke in the blue fractured ignimbrite sample, accompanied by a decrease in permeability, to $\sim 5 \times 10^{-18} \mathrm{~m}^{2}$. This decrease in permeability is the result of a decrease in microfractures and an increase in vugs, as revealed by our microstructural work (Figure 5). The vugs present in these samples are seen in the ash-sized pumices (Figure $5 \mathrm{C}-\mathrm{E}$ ). The porosity increases again at a distance of $4.55 \mathrm{~m}$ from the dyke, in the normal zeolitized ignimbrite, to about 0.2 , again accompanied by a decrease in permeability, to $\sim 1.5 \times 10^{-18} \mathrm{~m}^{2}$. Porosity and permeability are consistent for the two sample locations $>4 \mathrm{~m}$ from the dyke, showing a similar trend as the consistent Schmidt hammer rebound values at these locations (Figure 4).

Except for sample VK6, permeability decreases nonlinearly as a function of increasing connected porosity (Figure 7C), unlike many previous studies that show a non-linear permeability increase with increasing connected porosity [e.g. Farquharson et al. 2015]. As out- 
Table 2: Quantitative phase analysis for the rocks collected as a function of distance from the dyke (VK6, VK4, VK7, VK2, VK3, and VK5; see Figure 2 derived from X-ray powder diffraction analyses.

\begin{tabular}{|c|c|c|c|c|c|c|c|}
\hline & \multicolumn{6}{|c|}{ Sample number } \\
\hline & & VK6 & VK4 & VK7 & VK2 & VK3 & VK5 \\
\hline & Field description of sample & Dark & $\begin{array}{c}\text { Dark } \\
\text { perlitised }\end{array}$ & $\begin{array}{l}\text { Chocolate } \\
\text { pudding }\end{array}$ & $\begin{array}{c}\text { Blue } \\
\text { ignimbrite }\end{array}$ & $\begin{array}{l}\text { Zeolitized } \\
\text { ignimbrite }\end{array}$ & $\begin{array}{l}\text { Zeolitized } \\
\text { ignimbrite }\end{array}$ \\
\hline & Distance from dyke $(\mathrm{cm})$ & 45 & 205 & 280 & 305 & 455 & 705 \\
\hline \multirow{9}{*}{ 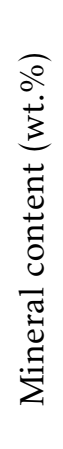 } & Amorphous phases (glass) & 0 & 52 & & 17 & 10 & 17 \\
\hline & Sanidine & 44 & 4 & & 4 & 5 & 4 \\
\hline & Plagioclase & 22 & 20 & 17 & 16 & 14 & 8 \\
\hline & Quartz & 27 & 3 & 3 & 3 & 3 & 2 \\
\hline & Biotite & 2 & $<1$ & & $<1$ & $<1$ & $<1$ \\
\hline & Magnetite, Ilmenite & 2 & 1 & & $<1$ & 1 & $<1$ \\
\hline & Clinoptilolite-Heulandite & & & 20 & 52 & 49 & 53 \\
\hline & Opal-CT & & 8 & & 7 & 17 & 15 \\
\hline & Smectite & 2 & 11 & 60 & & & \\
\hline
\end{tabular}

Table 3: Summary of the laboratory data (connected porosity and permeability) collected for this study. The experimental error on the measurements of porosity and permeability are $\ll 1 \%$ and $<1 \%$, respectively. Samples were either samples cored approximately perpendicular to dyke margin (X-direction) or approximately parallel to dyke margin (Y-direction).

\begin{tabular}{ccccc}
\hline Sample & Distance from dyke margin $(\mathrm{m})$ & Orientation & Connected porosity & Permeability $\left(\mathrm{m}^{2}\right)$ \\
\hline & & & & \\
VK6 & 0.45 & $\mathrm{X}$ & 0.02 & $<10^{-18}$ \\
VK6 & 0.45 & $\mathrm{X}$ & 0.02 & $<10^{-18}$ \\
VK6 & 0.45 & $\mathrm{Y}$ & 0.03 & $<10^{-18}$ \\
VK6 & 0.45 & $\mathrm{Y}$ & 0.01 & $<10^{-18}$ \\
VK4 & 2.05 & $\mathrm{X}$ & 0.07 & $1.37 \times 10^{-16}$ \\
VK4 & 2.05 & $\mathrm{X}$ & 0.06 & $3.61 \times 10^{-17}$ \\
VK4 & 2.05 & $\mathrm{Y}$ & 0.07 & $3.43 \times 10^{-16}$ \\
VK4 & Y & 0.07 & $2.02 \times 10^{-16}$ \\
VK2 & & $\mathrm{X}$ & 0.16 & \\
VK2 & 3.05 & $\mathrm{X}$ & 0.15 & $7.88 \times 10^{-18}$ \\
VK2 & 3.05 & $\mathrm{Y}$ & 0.14 & $5.02 \times 10^{-18}$ \\
VK2 & 3.05 & $\mathrm{Y}$ & 0.14 & $3.95 \times 10^{-18}$ \\
VK3 & 3.05 & $\mathrm{X}$ & 0.21 & $1.82 \times 10^{-18}$ \\
VK3 & 4.55 & $\mathrm{X}$ & 0.19 & $2.66 \times 10^{-18}$ \\
VK3 & 4.55 & $\mathrm{Y}$ & 0.21 & $1.50 \times 10^{-18}$ \\
VK3 & 4.55 & $\mathrm{Y}$ & 0.20 & $1.46 \times 10^{-18}$ \\
VK5 & 4.55 & $\mathrm{X}$ & 0.19 & $1.31 \times 10^{-18}$ \\
VK5 & 7.05 & $\mathrm{X}$ & 0.15 & $2.13 \times 10^{-18}$ \\
VK5 & 7.05 & $\mathrm{Y}$ & 0.20 & $1.15 \times 10^{-18}$ \\
\hline
\end{tabular}



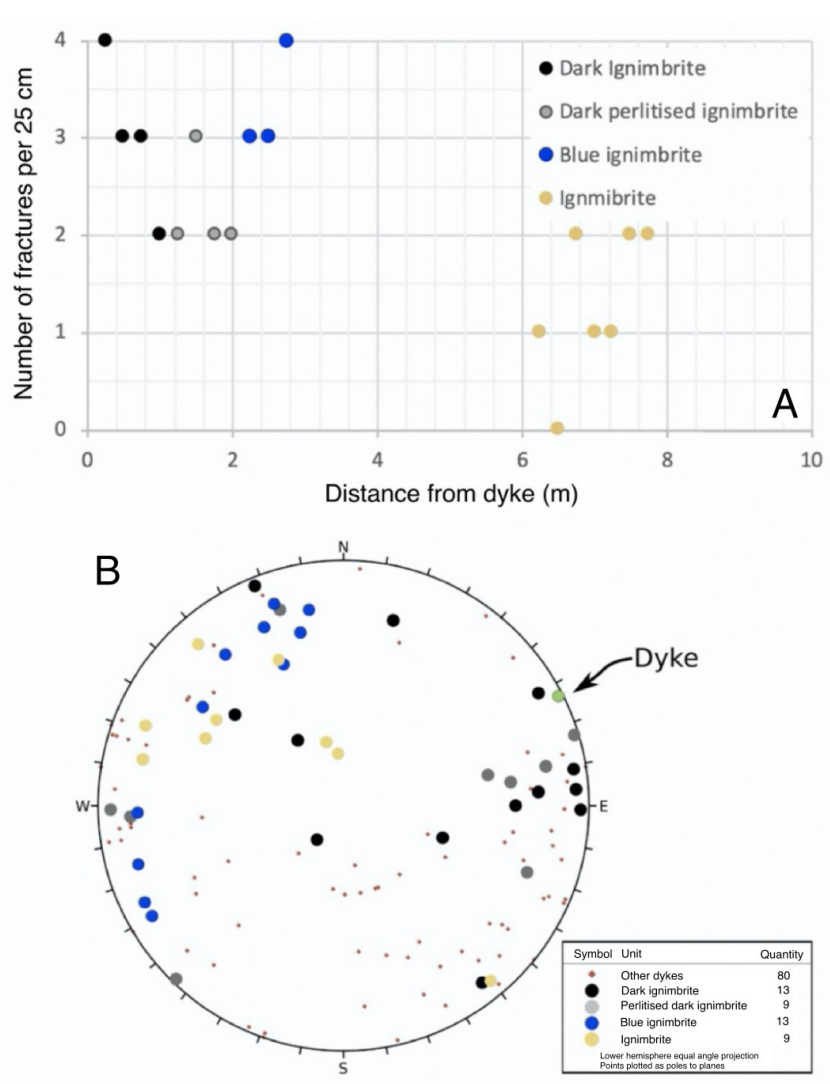

Figure 3: [A] Fracture spacing data recorded at scanline intersection binned every $25 \mathrm{~cm}$ to illustrate fracture density as a function of distance from the dyke margin. [B] Stereographic lower hemisphere, equal area projection of fracture orientations planes in the different rock types including comparison to the orientation of the dyke investigated in this study and other dykes in Hvítserkur measured in the field.

lined here, this initially counterintuitive relationship has a microstructural explanation, based on the partitioning of the void space (i.e. the relative proportions of microcracks and pores). Figure 7 shows that there is no systematic difference between the porosity and permeability of samples cored in the two orthogonal directions (X-direction, perpendicular to margin; Y-direction, parallel to margin), indicating that there is essentially no matrix permeability anisotropy in these materials. This is consistent with the lack of anisotropy revealed by the CT (Figure 6). Nonetheless, we do note that the permeability of the samples at the dyke margin are slightly, but consistently, more permeable in the Y-direction than in the X-direction (Figure 7B). This could be related to the microtextural alignment of glass shards seen in Figure 5A. However, we have been cautious in our interpretations of this permeability anisotropy due to uncertainty in the exact orientation of the samples, which were oriented in challenging conditions.

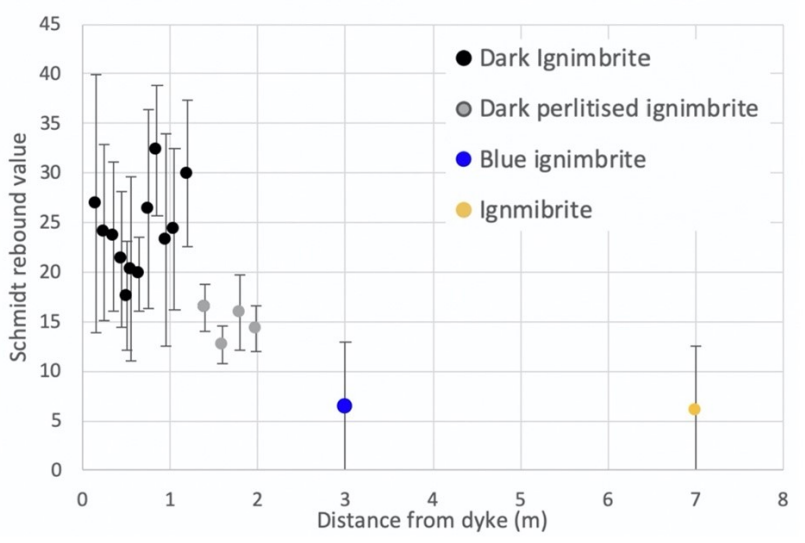

Figure 4: Schmidt hammer rebound values measured as a function of distance from the dyke margin. Symbol colours as in previous graph, and note many values were taken between 3 and $8 \mathrm{~m}$ from the dyke and all were below the detection limit of the Schmidt hammer. The Schmidt hammer rebound value is linked to rock strength and stiffness [e.g. Dinçer et al. 2004]. However, we prefer to show the rebound values here, rather than use empirical relationships that may invite error.

\section{Results Summary}

Our data show that ignimbrite field and laboratory properties vary systematically with distance from a six m-wide sub-vertical basaltic dyke, echoing the geomorphological expression (Figure 8). Within the first metre of the dyke margin, there are twelve fractures per metre in our ignimbrite scanline and the rock is characterised by high Schmidt rebound hammer values, low porosity and low permeability. These rocks contain a completely recrystallised groundmass of quartz, plagioclase, and alkali feldspar.

At 1-2.05 $\mathrm{m}$ from the dyke margin, there are about nine fractures per metre, and Schmidt hammer rebound values decreases, while laboratory permeability values show anomalously high permeability $\left(10^{-16} \mathrm{~m}^{2}\right)$ for its relatively low porosity (0.07); the SEM image of this sample showed pervasive perlitic microfractures, while a dominantly glassy texture was recorded by XRPD analysis.

At $2-3 \mathrm{~m}$ from the intrusion, the ignimbrite appears blue and contains 12 fractures per metre (i.e. 3 fractures per $25 \mathrm{~cm}$ ), Schmidt hammer rebound values were low or below detection, and despite a relatively high porosity, laboratory permeability measurements are lower than in the lower porosity ignimbrite closer to the dyke. The ignimbrite at this distance from the dyke contains about $38 \mathrm{wt}$.\% zeolite.

At distances $>3.05 \mathrm{~m}$, the fracture spacing is lower (4-5 fractures per metre) and the rock had unmeasurably low Schmidt hammer values. The ignimbrite remains zeolite rich (37-49 wt.\%) and has a generally high porosity of $0.15-0.2$ and relatively low laboratory permeability values. 

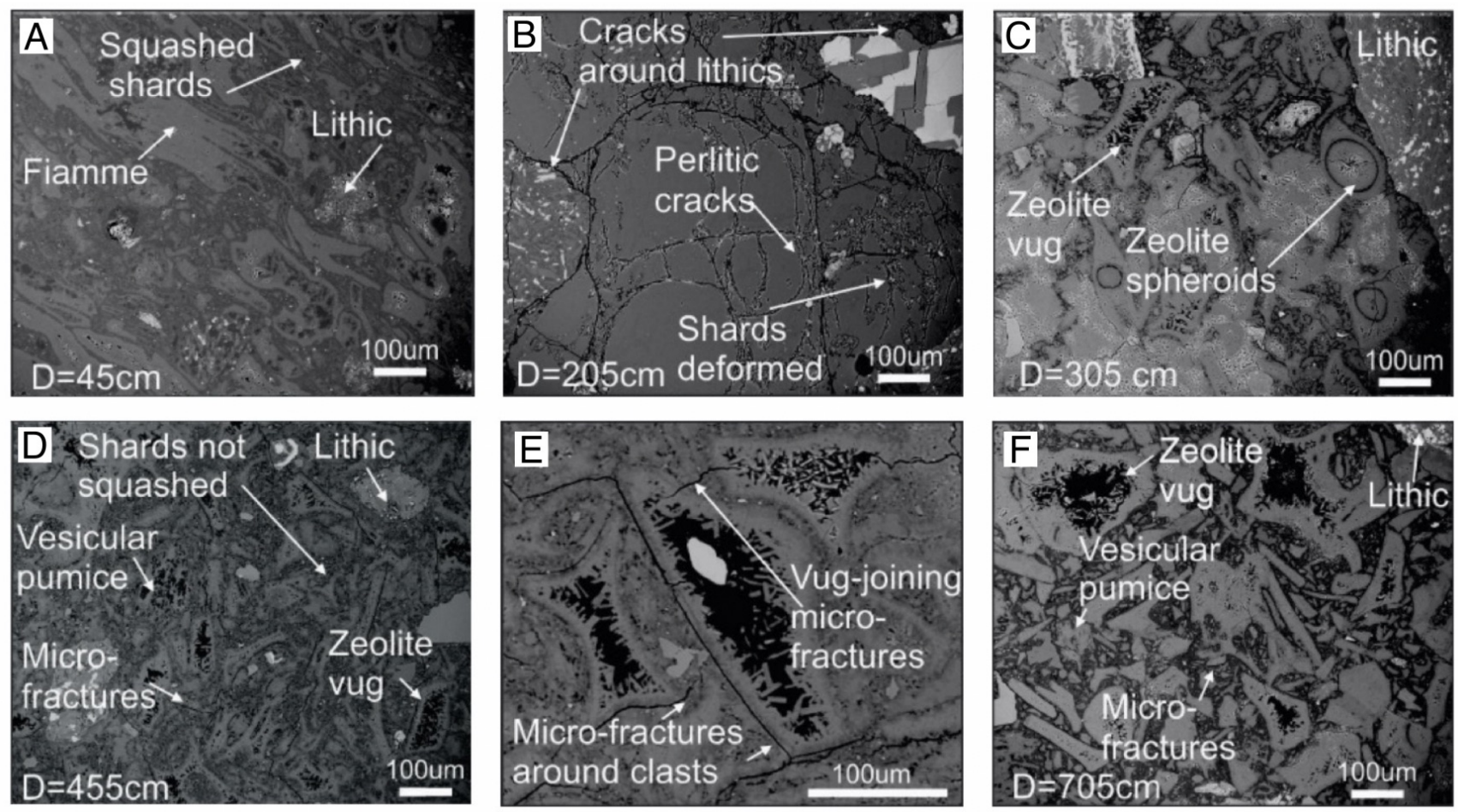

Figure 5: Scanning electron microscope (SEM) textures showing a transition from dense and glass-dominated ignimbrite close to the dyke to the zeolite and vug-dominated ignimbrite greater than $3 \mathrm{~m}$ from the dyke margin. [A] Dark welded ignimbrite (VK6), [B] perlitised dark ignimbrite (VK4), [C] blue ignimbrite (VK2). Images [D] and [E] are both the beige country rock ignimbrite from $455 \mathrm{~cm}$ from the dyke margin (VK3) shown at different magnifications. Image [F] is the also the beige country rock ignimbrite, but at $705 \mathrm{~cm}$ from the dyke margin (VK5).

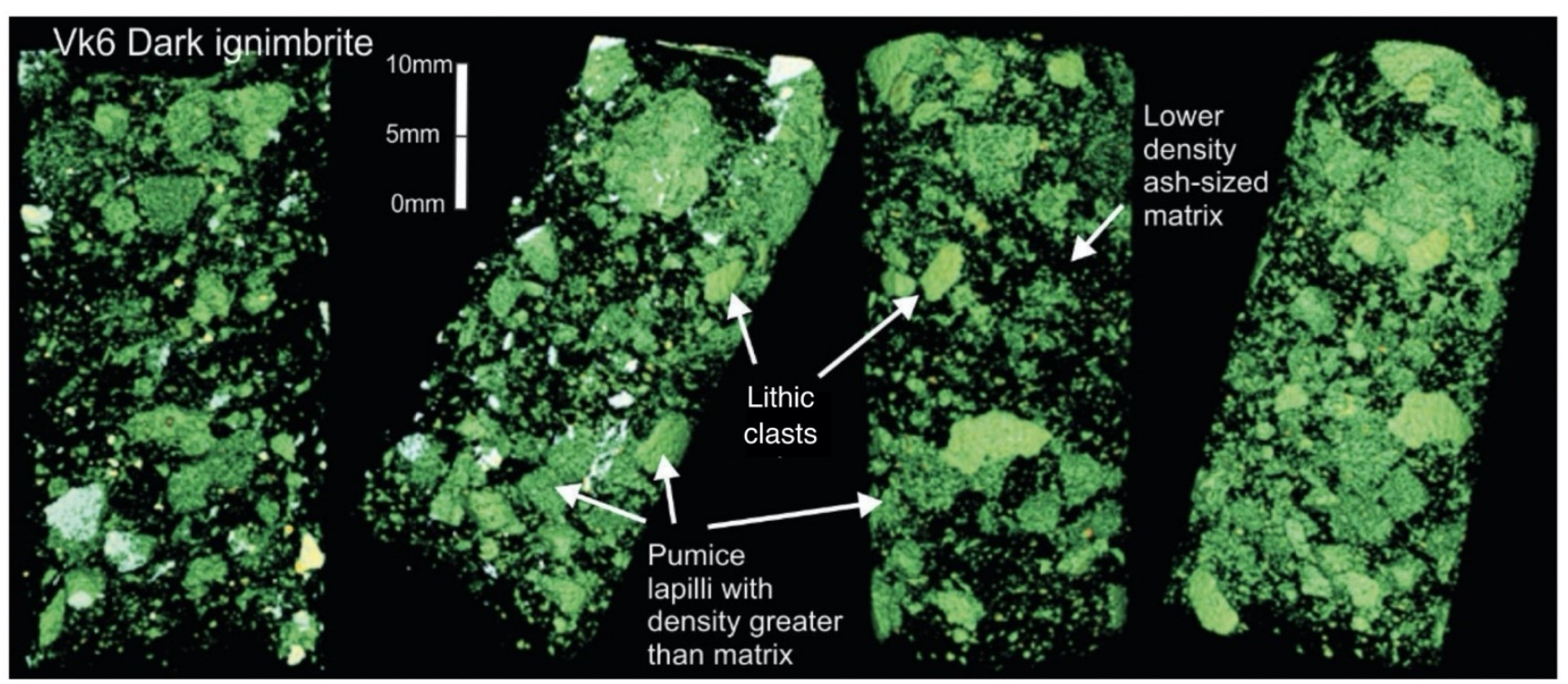

Figure 6: X-ray computed tomographic images showing shapes of lithic clasts and pumices in 3D (shown in green) on the sample scale of the dark ignimbrite (same sample rotated by $90^{\circ}$ through each subsequent image). The lapilli and coarse ash show no obvious alignment in any of the samples. Here, we show the dark welded ignimbrite (VK6) with no strong alignment of the larger clasts despite the microscopic flattened textures locally seen in the glass shards of the thin section. 

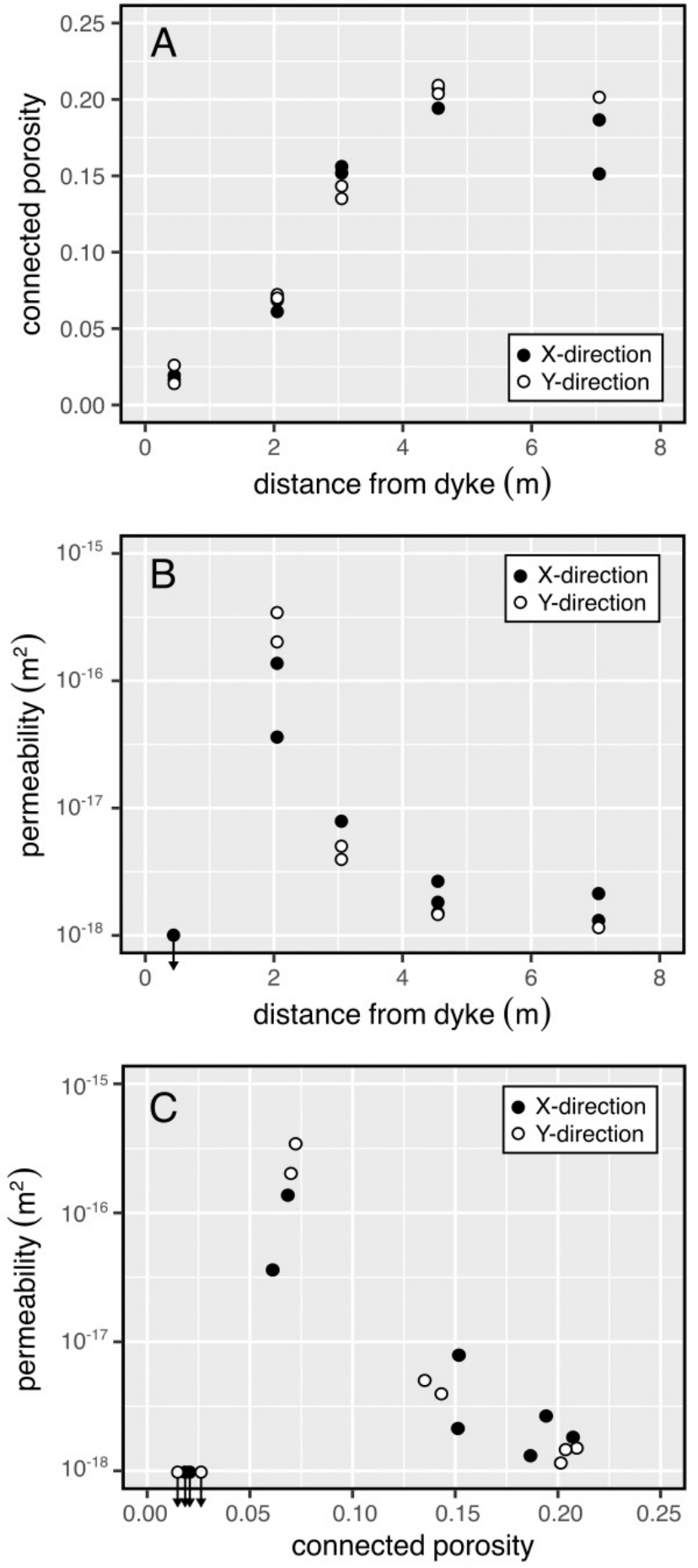

Figure 7: Laboratory measurements of connected porosity $[A]$ and permeability $[B]$ as a function of distance from the dyke margin. [C] Laboratory measurements of permeability as a function of connected porosity. Black symbols - samples cored in the X-direction (approximately perpendicular to dyke margin). White symbols - samples cored in the Y-direction (approximately parallel to dyke margin). The samples with the lowest porosity, $0.45 \mathrm{~m}$ from the dyke margin, were too low to be measured in our permeameter $\left(\ll 10^{-18} \mathrm{~m}^{2}\right)$, indicated by the arrow. The experimental error on the measurements of porosity and permeability are $\ll 1 \%$ and $<1 \%$, respectively, and so the error is encapsulated by the symbol size. Data available in Table 3.

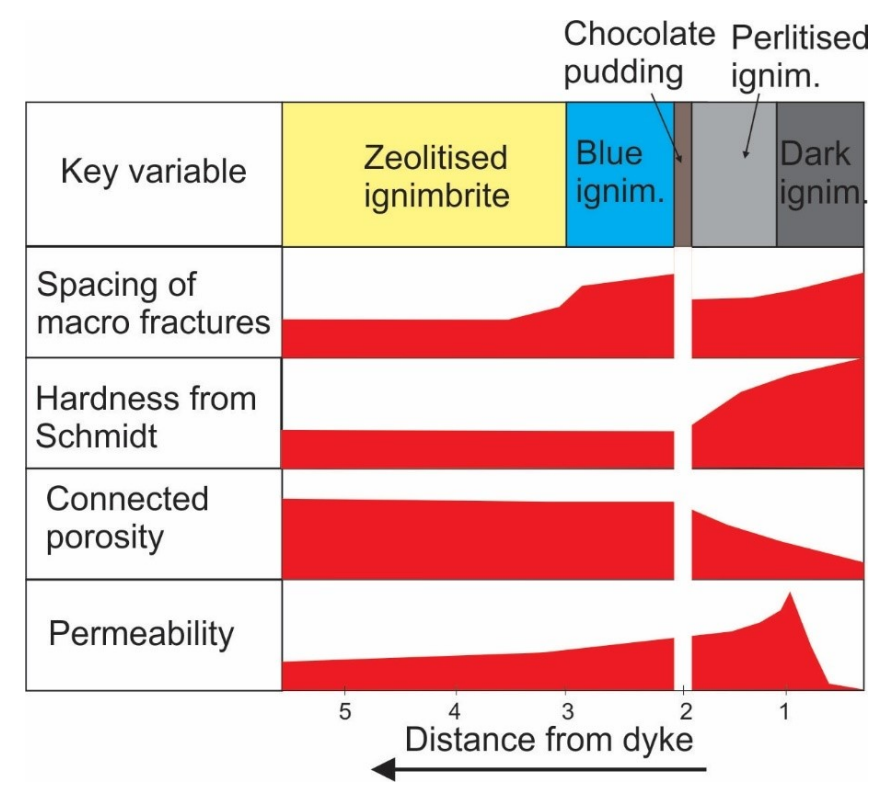

Figure 8: Summary of key results showing conceptualised relative results of each lithology, the height of the red area shows an approximation of the relative magnitude of the key variables as they change with distance from the dyke (in meters) at Hvítserkur mountain (East Iceland).

\section{Discussion}

Our results show that the six-metre-wide basaltic dyke carried sufficient thermal energy to significantly affect the mineralogical and physical properties of the ignimbrite to a distance of between 2 and $3 \mathrm{~m}$. These physical properties are manifest in the geomorphological expression of the $2 \mathrm{~m}$-thick walls of ignimbrite resistant to erosion either side of the dyke (Figure 2). These walls have high Schmidt hammer rebound values (approximation of hardness, strength, and stiffness), more fractures, and recrystallised quartz and feldspar and/or glassy welded textures. Between 2 and $3 \mathrm{~m}$ from the dyke margin there exists a zone with more macro-fractures (Figure 2B, Figure 3A) but with similar Schmidt hammer rebound values than the far-field ignimbrite (Figure 4).

Notably, the zeolite phases that constitute roughly half of the weight of the far-field ignimbrite $(>3 \mathrm{~m}$ from the dyke margin), are a common mineral in ignimbrites in Iceland [Walker 1960]. However, the intra-caldera ignimbrites in this study have distinctively high $\delta^{18} \mathrm{O}$ indicating secondary alteration and low temperature alteration that excludes simple meteoric exchange [Berg et al. 2018]. An interpretation of a locally elevated thermal gradient and low-temperature hydrothermal system is supported by pervasive presence of zeolite, and the presence of lake sediments within the caldera [Berg et al. 2018]. Our assumption for the model below is that the majority of the zeolitization occurred before the local dyke intruded, consis- 
tent with previous studies [Berg et al. 2018]. Therefore, dissolution cavities and zeolite growth (Figure 5) in the ignimbrite [e.g. Sruoga et al. 2004; Heap et al. 2020a] are responsible for the relatively high porosity and relatively low hardness/stiffness in the three ignimbrite samples furthest from the dyke (Figures 4 and 7).

Our interpretation is that when the dyke intruded through the ignimbrite, the heat from the basalt in the $0-2 \mathrm{~m}$ closest to dyke caused the glass in the ash shards and pumice lapilli in the ignimbrite to cross the glass transition $(\mathrm{Tg})$ and deform, a process similar to welding, which is common in many large pumiceous ignimbrites [e.g. Quane et al. 2009; Wadsworth et al. 2019; 2021]. Although the temperature and water content are not available to constrain $\mathrm{Tg}$, it is likely to be $700 \pm 100^{\circ} \mathrm{C}$ [Krafla rhyolite; Castro et al. 2008]. Welding and sintering can help to reduce porosity and increase strength and Young's modulus [Vasseur et al. 2013; Heap et al. 2015], as seen in our Schmidt hammer measurements (Figure 4).

In a typical welded ignimbrite, shards and pumice lapilli are flattened horizontal to the surface of the Earth and perpendicular to gravity [Wolff and Wright 1981; Walker 1983]. Compaction and porosity loss via surface tension are also possible without creating strong fabrics [Kennedy et al. 2016]. Our hand samples did not show evidence of strong fabrics (Figure 5). Additionally, in some welded ignimbrites, flow can occur post deposition and subject the deposit to pure and/or simple shear, thereby elongating deformable particles and generating a rheomorphic texture [Wolff and Wright 1981].

The cooling rate of the ignimbrite affects solidification processes and the generation of fractures, and a complex interplay can occur between crystallisation, the glass transition and sub solidus and/or vapour phase crystallisation. Closest to the dyke in the dark welded ignimbrite, the highest temperatures and longest timescales of temperatures above Tg allowed for quartz and feldspar recrystallisation. In the dark perlitised ignimbrite and dark ignimbrite within $2 \mathrm{~m}$ of the dyke, textural evidence shows glass deformed as ash shards can be seen locally flattened. Beyond $2 \mathrm{~m}$ from the dyke, there is no evidence of deformed glass shards and temperatures must have been below Tg.

The macro-fracture sets measured in the field in the dark ignimbrite have some similarity to those preserved at the margins of rhyolitic intrusions [e.g. Saubin et al. 2019]. Fractures closest to the dyke are generally parallel with the dyke NNW-SSE, and are therefore likely related to expansion during heating followed by cooling contraction [e.g. Lamur et al. 2018], or are similar to the NE-SW regional trend. Our field results report orthogonal cooling joints had not fully developed, although the blue ignimbrite 2-3 $\mathrm{m}$ from the dyke margin has a well-developed fracture set with orientations clustered NE-SW as well as NNW-SSE, and on the other side of the dyke similar fractures can be seen with mirror orientations. The direction of these fractures may be related to stresses during dyke propagation to the surface similar to relationships seen at the margins of dykes and sills in other areas of Iceland [Saubin et al. 2019]. Farther than $3 \mathrm{~m}$ from the dyke margin, the fractures trend more dominantly NNE-SSW. The presence of these macro-fractures suggests that the rock-mass permeability (outcrop to edifice scale) is likely characterised by a permeability anisotropy not captured in our hand specimen scale laboratory matrix permeability measurements (Figure 7), as discussed in Vasseur and Wadsworth [2019], which varies with distance from the dyke margin.

The margin of the glassy wall has developed perlitised micro-cracks, seen in our microstructural work (Figure 5). Water content gradients and compositions are not available to constrain the timescale of perlitic fractures that were found in the sample $2.05 \mathrm{~m}$ from the dyke; however, an approximation could be gained from comparison to the temperature and time window indicated by von Aulock et al. [2013]: $\sim 400^{\circ} \mathrm{C}$ and on a timescale of days. Hydration is also necessary in the development of perlitic cracks [e.g. Denton et al. 2009]. Therefore, the hydrothermal system may have been pervasively migrating inwards towards the glassy barrier of the dyke. The glassy textures in the wall of welded ignimbrite were preserved despite this locally high permeability facilitated by the perlitic microcracks. This observation implies fluid flow has not occurred extensively within these glassy rocks, as prolonged exposure of volcanic glass to geothermal fluids results in zeolite and clay alteration [e.g. Denton et al. 2009; 2012]. However, adjacent to this layer is the smectite-rich layer (represented by the "chocolate pudding" sample) that is extensively altered, losing all strength.

We suggest that micro-fractures from extensive perlitisation and the intersection of NNW-SSE dyke-parallel and NE-SW macro-fractures facilitated fluid flow and alteration in the area of the smectite-rich layer that resembles chocolate pudding. Similar association between alteration and perlitisation and fluid flow have been seen at geothermal fields [Giorgetti et al. 2006]. To facilitate this complete alteration and disaggregation, this heavily fractured dyke-parallel sheet must have experienced sustained fluid flow. In contrast, the majority of the ignimbrite away from the dyke is heavily zeolitized with a high porosity, but low macro- and microfracture density, resulting in relatively low matrix and rock mass permeability, implying fluid flow was highly restricted to the affected rock masses immediately adjacent to the dyke. Although not investigated here, it is worth noting that the dyke itself is highly fractured and eroded and may have been an additional vertical channel for fluid flow [e.g. Spacapan et al. 2020].

The zeolites appear to have been entirely thermally decomposed within the near-dyke samples. Thermogravimetric studies of the thermal stability of zeo- 
lites have shown that both clinoptilolite and heulandite undergo irreversible dehydration at temperatures of around $300{ }^{\circ} \mathrm{C}$ [Cruciani 2006], although dehydration temperatures are sensitive to grainsize and environmental humidity. The vast majority of clinoptilolite dehydration occurs at $<300^{\circ} \mathrm{C}$ [Feldman et al. 2020]. Heulandite undergoes a structural collapse on heating above a threshold that varies between 175$360^{\circ} \mathrm{C}$, depending on its composition, and this manifests as a thermal contraction, with a volume reduction of up to $26 \%$ accompanying thermally-driven dehydration [Cruciani 2006]. We suggest that the inferred $1130^{\circ} \mathrm{C}$ crystallisation temperature of the dyke [Gestsson 2018] was sufficient to decompose zeolites, destroy porosity and generate melt sufficient for both welding and recrystallisation. However, we cannot discount some additional retrograde zeolite formation as the dyke cooled.

The welding process reduced the porosity and sample matrix permeability of the host ignimbrite nearest the dyke. At the outer margin of the alteration zone, where the thermal window is appropriate for perlitisation [von Aulock et al. 2013], the porosity remains lower than the far-field porosity while sample matrix permeability is three orders of magnitude higher than the far-field sample matrix permeability. Our physical property and mineralogical data can constrain the thermal gradient around the dyke. The plagioclasemelt equilibrium thermobarometer of Putirka [2008] constrained the temperature of the dyke to be $1130^{\circ} \mathrm{C}$ [Gestsson 2018]. Our data show that the temperature within the $2 \mathrm{~m}$ closest to the dyke was sufficient for ductile shard deformation on the timescale of dyke emplacement and therefore at a temperature above the glass transition for this rhyolite on this timescale. The zeolites appear ubiquitous at distances $>205 \mathrm{~cm}$ from the dyke margin and were identified as clinoptiloliteheulandite indicating a temperature $<300{ }^{\circ} \mathrm{C}$ [Kirov et al. 1979; Feldman et al. 2020]. However, the thoroughly altered smectite sheet and the presence of smectite in the dark perlitised ignimbrite indicate that, following local heating from the dyke, the newly created permeability associated with the micro- and macro-fractures allowed prolonged exposure to fluid flow at temperatures elevated above the geothermal gradient, although below $100{ }^{\circ} \mathrm{C}$. Nevertheless, further smectite chemistry and more knowledge of the fluid chemistry would be necessary to constrain the temperature range required for their formation [Kloprogge 1999].

\section{Implications AND Conclusions}

Most large silicic magma chambers associated with calderas have bi- or multimodal magma chemistries [Troll 2002; Kennedy et al. 2018], and basaltic dykes and sills have been evoked within many magmatic systems [e.g. Leonard et al. 2002]. Caldera magma sys- tems also frequently host active or fossil geothermal systems [Garden et al. 2020] or epithermal mineral resources [Nadeau et al. 2015; Heap et al. 2020a]. Our study shows the thermal effects of basaltic dykes on the properties of host ignimbrite produces spatially changing permeability and porosity and has implications for sub-vertical (dyke-parallel) planes of high permeability adjacent to parallel planes of low permeability.

We interpret the following sequence of events: (1) the ignimbrite was deposited, and buried to a sufficient depth and temperature to allow zeolitization from warm $\left(<300^{\circ} \mathrm{C}\right)$ fluids permeating through pathways between and around pumice clasts in various states of dissolution and recrystallisation (Figure 5D-F). Volumetric changes during zeolite crystallisation may have additionally created microfractures (Figure 5E). (2) A locally focussed basaltic dyke swarm intruded (oriented NNE-SSW to NE-SW) into the ignimbrite; one of which was the 6-meter-wide dyke investigated in this study. This dyke melted the ignimbrite within $1 \mathrm{~m}$, causing welding and densification to create an impermeable layer. 1-2 $\mathrm{m}$ away from the dyke, the glass was preserved but formed cracks during cooling that created hydrated perlitised microfractures. (3) This vertical zone of perlitic microfractures and macrofractures adjacent to the dense impermeable barrier then acted as a vertical structure that prevented the lateral flow of fluids from the country rock ignimbrite, but facilitated vertical flow of warm hydrothermal fluids $\left(<100^{\circ} \mathrm{C}\right)$. This fluid circulation completely alteration the most fractured perlitic ignimbrite to a vertical sheet of clay. We envisage similar processes occurring within the ignimbrite associated with the rest of the dykes at Hvitserkur (Figure 1B).

This allows us to create a conceptual compartmen-

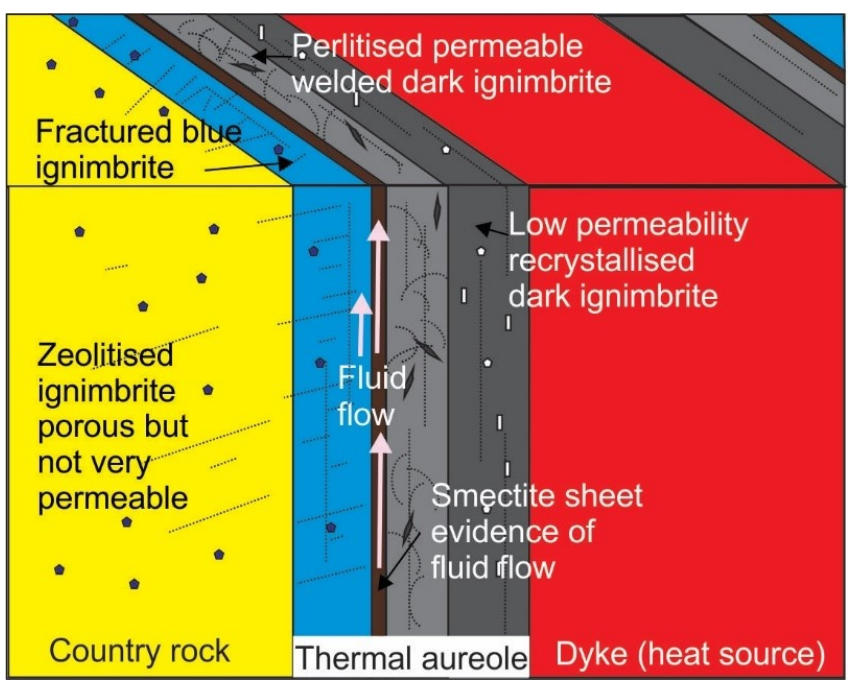

Figure 9: Conceptual diagram of the dyke at Hvítserkur mountain (East Iceland) and its thermal aureole. Also provided is our interpretation of the fluid flow zone. The width of the thermal aureole is about $3 \mathrm{~m}$. 
talised hydrothermal model controlled by the dykes where vertical macro- and micro-fractured permeable planes with low porosity are adjacent to vertical "impermeable" planes approximately $1 \mathrm{~m}$ wide within a porous but low permeability ignimbrite. The result is a conceptual model where fluid can be highly channelised into vertical pathways $<1 \mathrm{~m}$ in width (Figure 9). Our evidence for this is seen by the vertical plane of strengthless and completely disaggregated smectite parallel to the very hard and low-permeability welded ignimbrite. Modellers of fluid flow within volcanoes and geothermal systems should be aware of the potentially common occurrence of such vertical channels for, and barriers to, fluid flow in ignimbrites intruded by dykes. If we assume that other dykes have the same physical properties as the studied dyke, then fluid flow through the ignimbrite body would have been disrupted in every direction, although it is likely that more vertical compartments (and channels) could have possibly formed parallel to the majority of subvertical dykes.

The implication of barriers and channels is a hydrothermal/geothermal system that is highly compartmentalised with the potential for localised convective regions where permeability allows fluid flow. This is consistent with the role of igneous intrusions in petroleum migration. For example, some studies describe examples of intrusions that act as both barriers and channels, compartmentalising horizontal flow and either extending or blocking vertical flow [Rateau et al. 2013; Senger et al. 2017]. Three-dimensional seismic surveys also emphasise the importance of considering the 3D structure of the intrusion and subsequent compartments [Senger et al. 2013]. Similarly, 3D views of dykes from seismic imaging illustrate the role of segmentation in dykes [Magee and Jackson 2020], which is also evident in field exposures [e.g. Brown et al. 2007] and can be seen at Hvítserkur (Figure 2A). Additionally, compartments within hydrothermal systems with relatively thin (i.e. $1 \mathrm{~m}$ ) seals have implications for hydrothermal explosions [e.g. Kennedy et al. 2020; Montanaro et al. 2020]. A blockage may allow overpressure to develop within a hydrothermal system, encouraging explosive behaviour [e.g. Heap et al. 2019] and exacerbating slope instability [e.g. Heap et al. 2021b]. An investigation of the influence of compartmentalisation in 3D on regional fluid flow using large-scale modelling could be a fruitful area of future research.

We conclude that: (1) basaltic dykes can drive welding over $2-3 \mathrm{~m}$ in an ignimbrite creating a lowpermeability dense glassy rock with 7-12 macrofractures per metre. (2) Towards the margin of this welded zone, perlitisation can locally create a micro-fracture network that facilitates a zone of high permeability. (3) The lack of alteration in this perlitised zone, in contrast to the completely altered cohesionless vertical zone immediately adjacent to it, implies that fluid flow occurred dominantly adjacent to the perlitised zone. (4)
Our data, which also provide a unique dataset where porosity negatively correlates with permeability, highlight how fluid flow can be compartmentalised by alteration and micro-fracturing resulting from dyke emplacement, and that generally accepted porosity and permeability relationships may not be appropriate for these rock masses.

\section{ACKNOWLedgements}

BK acknowledges NZ MBIE catalyst grant energy straight from magma. Permission to export samples from Iceland was granted by the Icelandic Institute of Natural History. We thank Rob Spiers, Shaun Mucalo, and Bertrand Renaudie for preparing the laboratory samples. MJH acknowledges support from the Institut Universitaire de France (IUF). MJH and HT are indebted to the Royal Society International Exchanges program. HT was supported by Royal Society University Research Fellowship UF140716. EBG and SB acknowledge support by Landsvirkjun through a student research grant awarded to EBG. ND, MA, and PB acknowledge the support of the entire MARS collaboration. We thank Richard Brown and Stephan Pansino for constructive reviews.

\section{Author COntributions}

BK conceptualised the paper, analysed the data, and wrote the manuscript. All authors contributed to the editing and revising of the manuscript. $\mathrm{MJH}$ measured the porosity and permeability of the samples in the laboratory. SB carried out field measurements of dykes and mapping of the Breiðuvík caldera. MCV conducted the structural analysis. HAG conducted the XRPD analysis. BK, HT, ES, EBG, JD, and SB carried out the field measurements and sampling of the dyke and ignimbrite. ND performed the X-ray imaging of the ignimbrite samples with the MARS Spectral CT scanner. This included protocol optimisation, scanning, visualisation and data analysis using MATLAB coding. MA and $\mathrm{PB}$ assisted ND in optimising the scanning protocol.

\section{Data AVAILABility}

The processed data collected for this study can be found in Tables 2 and 3. Raw data is available on request from the authors.

\section{COPYRIGHT NOTICE}

(c) The Author(s) 2022. This article is distributed under the terms of the Creative Commons Attribution 4.0 International License, which permits unrestricted use, distribution, and reproduction in any medium, pro- 
vided you give appropriate credit to the original author(s) and the source, provide a link to the Creative Commons license, and indicate if changes were made.

\section{REFERENCES}

Anjomrouz, M. (2017). "Investigation of MARS spectral CT: X-ray source and detector characterization". PhD thesis. University of Otago, New Zealand.

Annen, C. (2017). "Factors Affecting the Thickness of Thermal Aureoles". Frontiers in Earth Science 5. DoI: 10.3389/feart.2017.00082.

Árnason, K. (2020). "New Conceptual Model for the Magma-Hydrothermal-Tectonic System of Krafla, NE Iceland". Geosciences 10(1), p. 34. Dor: $10.3390 /$ geosciences 10010034 .

Ball, J. L., J. Taron, M. E. Reid, S. Hurwitz, C. Finn, and P. Bedrosian (2018). "Combining Multiphase Groundwater Flow and Slope Stability Models to Assess Stratovolcano Flank Collapse in the Cascade Range". Journal of Geophysical Research: Solid Earth 123(4), pp. 2787-2805. DOI: 10.1002/2017jb015156.

Barberi, F., A. Bertagnini, P. Landi, and C. Principe (1992). "A review on phreatic eruptions and their precursors". Journal of Volcanology and Geothermal Research 52(4), pp. 231-246. DOI: 10 . 1016/0377 0273 (92) 90046 - g.

Berg, S. E., V. R. Troll, C. Harris, F. M. Deegan, M. S. Riishuus, S. Burchardt, and M. Krumbholz (2018). "Exceptionally high whole-rock $\delta 180$ values in intracaldera rhyolites from Northeast Iceland". Mineralogical Magazine 82(5), pp. 1147-1168. Dor: $10.1180 /$ mgm. 2018. 114 .

Bergmann, J., P. Friedel, and R. Kleeberg (1998). "BGMN-a new fundamental parameters based Rietveld program for laboratory X-ray sources, its use in quantitative analysis and structure investigations". CPD Newsletter 20(5).

Bertrand, E. A., T. G. Caldwell, G. J. Hill, E. L. Wallin, S. L. Bennie, N. Cozens, S. A. Onacha, G. A. Ryan, C. Walter, A. Zaino, and P. Wameyo (2012). "Magnetotelluric imaging of upper-crustal convection plumes beneath the Taupo Volcanic Zone, New Zealand". Geophysical Research Letters 39(2). Dor: 10. 1029/2011gl050177.

Bibby, H., T. Caldwell, F. Davey, and T. Webb (1995). "Geophysical evidence on the structure of the Taupo Volcanic Zone and its hydrothermal circulation". Journal of Volcanology and Geothermal Research 68(13), pp. 29-58. Dor: 10.1016/0377-0273 (95) 00007-h.

Bischoff, A., M. Rossetti, A. Nicol, and B. Kennedy (2019). "Seismic reflection and petrographic interpretation of a buried monogenetic volcanic Field (part 1)”. Bulletin of Volcanology 81(9). Dor: 10.1007/ s๑๑445-๑19-1316-7.
Bixley, P. and P. Browne (1988). "Hydrothermal eruption potential in geothermal development". Proceedings of the 10th New Zealand Geothermal Workshop, pp. 195-198.

Brace, W. F., J. B. Walsh, and W. T. Frangos (1968). "Permeability of granite under high pressure". Journal of Geophysical Research 73(6), pp. 2225-2236. DOI: 10.1029/jb073i006p02225.

Bromley, C. and M. Mongillo (1994). "Hydrothermal eruptions-a hazard assessment". Proceedings of the 16th New Zealand Geothermal Workshop, pp. 45-50.

Brown, R., J. Kavanagh, R. Sparks, M. Tait, and M. Field (2007). "Mechanically disrupted and chemically weakened zones in segmented dike systems cause vent localization: Evidence from kimberlite volcanic systems". Geology 35(9), p. 815. DoI: 10 . 1130/g23670a. 1.

Browne, P. and J. Lawless (2001). "Characteristics of hydrothermal eruptions, with examples from New Zealand and elsewhere". Earth-Science Reviews 52(4), pp. 299-331. Dor: 10.1016/s0012-8252(00)00030-1.

Bruhn, R. L., W. A. Yonkee, and W. T. Parry (1990). "Structural and fluid-chemical properties of seismogenic normal faults". Tectonophysics 175(1-3), pp. 139-157. DoI: 10.1016/0040-1951(90)90135-u.

Burchardt, S. (2008). "New insights into the mechanics of sill emplacement provided by field observations of the Njardvik Sill, Northeast Iceland". Journal of Volcanology and Geothermal Research 173(3-4), pp. 280288. DoI: $10.1016 / \mathrm{j}$. jvolgeores. 2008.02.009.

Burchardt, S., B. Oskarsson, L. Gustafsson, S. Berg, and M. Riishuus (2021). "Geology of a Neogene caldera cluster in Northeast Iceland - clues into rift zone architecture on a young Iceland". Dor: 10.31223/ $\mathrm{x} 5 \mathrm{~m} 04 \mathrm{~h}$.

Burchardt, S., D. C. Tanner, V. R. Troll, M. Krumbholz, and L. E. Gustafsson (2011). "Three-dimensional geometry of concentric intrusive sheet swarms in the Geitafell and the Dyrfjöll volcanoes, eastern Iceland". Geochemistry, Geophysics, Geosystems 12(7). DOI: $10.1029 / 2011 \mathrm{gc} 003527$.

Caine, J. S., J. P. Evans, and C. B. Forster (1996). "Fault zone architecture and permeability structure". Geology 24(11), p. 1025. DOI: $10.1130 / 0091-7613$ (1996) $024<1025$ : fzaaps $>2$. 3. co; 2 .

Caine, J. S. and C. B. Forster (1999). "Fault zone architecture and fluid flow: Insights from field data and numerical modeling". Geophysical MonographAmerican Geophysical Union 113, pp. 101-128.

Castro, J. M., P. Beck, H. Tuffen, A. R. Nichols, D. B. Dingwell, and M. C. Martin (2008). "Timescales of spherulite crystallization in obsidian inferred from water concentration profiles". American Mineralogist 93(11-12), pp. 1816-1822. DoI: 10.2138 / am . 2008 . 2904. 
Cavazos-Álvarez, J. A., G. Carrasco-Núñez, P. DávilaHarris, D. Peña, A. Jáquez, and D. Arteaga (2020). "Facies variations and permeability of ignimbrites in active geothermal systems; case study of the Xáltipan ignimbrite at Los Humeros Volcanic Complex". Journal of South American Earth Sciences 104, p. 102810. DoI: $10.1016 / j$. jsames . 2020.102810.

Cello, G., C. Invernizzi, S. Mazzoli, and E. Tondi (2001). "Fault properties and fluid flow patterns from Quaternary faults in the Apennines, Italy". Tectonophysics 336(1-4), pp. 63-78. DOI: 10.1016/s0040-1951(๑1) ๑००94-4.

Chevallier, L. and A. Woodford (1999). "Morphotectonics and mechanism of emplacement of the dolerite rings and sills of the western Karoo, South Africa". South African Journal of Geology 102(1), pp. 43-54.

Cruciani, G. (2006). "Zeolites upon heating: Factors governing their thermal stability and structural changes". Journal of Physics and Chemistry of Solids 67(9-10), pp. 1973-1994. DoI: 10.1016/j . jpcs. 2006. 05.057.

Day, S. J. (1996). "Hydrothermal pore fluid pressure and the stability of porous, permeable volcanoes". Geological Society, London, Special Publications 110(1), pp. 77-93. DoI: 10.1144/gsl.sp.1996.110.01.06.

De Ruiter, N. (2015). "Algorithms to process data from the MARS molecular imaging system". PhD thesis. University of Otago, New Zealand.

Deere, D. U. and R. Miller (1966). Engineering classification and index properties for intact rock. Tech. rep. Illinois Univ At Urbana Dept Of Civil Engineering.

Del Potro, R. and M. Hürlimann (2008). "Geotechnical classification and characterisation of materials for stability analyses of large volcanic slopes". Engineering Geology 98(1-2), pp. 1-17. DoI: 10.1016/j . enggeo . 2007.11.007.

Delcamp, A., G. Roberti, and B. van Wyk de Vries (2016). "Water in volcanoes: evolution, storage and rapid release during landslides." Bulletin of Volcanology 78(12). DOI: $10.1007 / \mathrm{s} 00445-016-1082-8$.

Denton, J., H. Tuffen, and J. Gilbert (2012). "Variations in hydration within perlitised rhyolitic lavas-evidence from Torfajökull, Iceland". Journal of Volcanology and Geothermal Research 223-224, pp. 64-73. DoI: 10.1016/j . jvolgeores. 2012.02.005.

Denton, J., H. Tuffen, J. Gilbert, and N. Odling (2009). "The hydration and alteration of perlite and rhyolite". Journal of the Geological Society 166(5), pp. 895904. DOI: $10.1144 / 0016-76492008-007$.

Dinçer, I., A. Acar, I. Çobanoğlu, and Y. Uras (2004). "Correlation between Schmidt hardness, uniaxial compressive strength and Young's modulus for andesites, basalts and tuffs". Bulletin of Engineering Geology and the Environment 63(2), pp. 141-148. DoI: $10.1007 / \mathrm{s} 10064-004-0230-0$.
Doebelin, N. and R. Kleeberg (2015). "Profex: a graphical user interface for the Rietveld refinement programBGMN". Journal of Applied Crystallography 48(5), pp. 1573-1580. DOI: $10.1107 /$ s1600576715014685.

Duncan, N. J. K. (2021). "MARS imaging for geology". PhD thesis. University of Canterbury.

Evans, J. P., C. B. Forster, and J. V. Goddard (1997). "Permeability of fault-related rocks, and implications for hydraulic structure of fault zones". Journal of Structural Geology 19(11), pp. 1393-1404. Dor: 10 . 1016/s0191-8141(97) $00057-6$.

Farquharson, J. I., M. J. Heap, N. R. Varley, P. Baud, and T. Reuschlé (2015). "Permeability and porosity relationships of edifice-forming andesites: A combined field and laboratory study". Journal of Volcanology and Geothermal Research 297, pp. 52-68. DOI: 10 . 1016/j. jvolgeores. 2015.03.016.

Farquharson, J. I., B. Wild, A. R. L. Kushnir, M. J. Heap, P. Baud, and B. Kennedy (2019). "Acid-Induced Dissolution of Andesite: Evolution of Permeability and Strength". Journal of Geophysical Research: Solid Earth 124(1), pp. 257-273. Dor: 10.1029/2018jb016130.

Feldman, J., M. Paul, G. Xu, D. X. Rademacher, J. Wilson, and T. M. Nenoff (2020). "Effects of natural zeolites on field-scale geologic noble gas transport". Journal of Environmental Radioactivity 220-221, p. 106279. Dor: 10.1016/j . jenvrad.2020.106279.

Finn, C. A., M. Deszcz-Pan, J. L. Ball, B. J. Bloss, and B. J. Minsley (2018). "Three-dimensional geophysical mapping of shallow water saturated altered rocks at Mount Baker, Washington: Implications for slope stability". Journal of Volcanology and Geothermal Research 357, pp. 261-275. DoI: $10.1016 / \mathrm{j}$. jvolgeores . 2018.04.013.

Fitzgerald, R. H., K. Tsunematsu, B. M. Kennedy, E. C. P. Breard, G. Lube, T. M. Wilson, A. D. Jolly, J. Pawson, M. D. Rosenberg, and S. J. Cronin (2014). "The application of a calibrated 3D ballistic trajectory model to ballistic hazard assessments at Upper Te Maari, Tongariro". Journal of Volcanology and Geothermal Research 286, pp. 248-262. DoI: 10.1016/j . jvolgeores. 2014.04.006.

Forchheimer, P. (1901). "Wasserbewegung durch boden". Zeitschrift des Vereines Deutscher Ingenieure 45, pp. 1782-1788. [In German].

Galland, O., S. Burchardt, E. Hallot, R. Mourgues, and C. Bulois (2014). "Dynamics of dikes versus cone sheets in volcanic systems". Journal of Geophysical Research: Solid Earth 119(8), pp. 6178-6192. DoI: 10 . $1002 / 2014 \mathrm{jb} 011059$.

Garden, T. O., I. Chambefort, D. M. Gravley, C. D. Deering, and B. M. Kennedy (2020). "Reconstruction of the fossil hydrothermal system at Lake City caldera, Colorado, U.S.A.: Constraints for calderahosted geothermal systems". Journal of Volcanology and Geothermal Research 393, p. 106794. DoI: 10 . 1016/j . jvolgeores. 2020.106794. 
Garden, T. O., D. M. Gravley, B. M. Kennedy, C. Deering, and I. Chambefort (2017). "Controls on hydrothermal fluid flow in caldera-hosted settings: Evidence from Lake City caldera, USA". Geosphere 13(6), pp. 1993-2016. Dor: 10.1130/ges01506.1.

Gestsson, E. B. (2018). "Geothermal Potential of SubVolcanic Intrusions in a Typical Caldera Setting". Master's thesis. Uppsala University, Sweden.

Giorgetti, G., T. Monecke, R. Kleeberg, and M. D. Hannington (2006). "Low-temperature hydrothermal alteration of silicic glass at the PACMANUS hydrothermal vent field, Manus basin: an XRD, SEM and AEMTEM study". Clays and Clay Minerals 54(2), pp. 240251. DoI: $10.1346 / \mathrm{ccmn} .2006 .0540209$.

Gudmundsson, A. (2002). "Emplacement and arrest of sheets and dykes in central volcanoes". Journal of Volcanology and Geothermal Research 116(3-4), pp. 279298. DoI: $10.1016 / \mathrm{s} 0377-0273(02) 00226-3$.

Harnett, C. E., J. E. Kendrick, A. Lamur, M. E. Thomas, A. Stinton, P. A. Wallace, J. E. P. Utley, W. Murphy, J. Neuberg, and Y. Lavallée (2019). "Evolution of Mechanical Properties of Lava Dome Rocks Across the 1995-2010 Eruption of Soufrière Hills Volcano, Montserrat". Frontiers in Earth Science 7. DoI: 10 . 3389/feart. 2019.00007.

Heap, M. J., J. I. Farquharson, F. B. Wadsworth, S. Kolzenburg, and J. K. Russell (2015). "Timescales for permeability reduction and strength recovery in densifying magma". Earth and Planetary Science Letters 429, pp. 223-233. Dor: 10.1016/j . epsl.2015.07.053.

Heap, M. J., T. S. Baumann, M. Rosas-Carbajal, J.-C. Komorowski, H. A. Gilg, M. Villeneuve, R. Moretti, P. Baud, L. Carbillet, C. Harnett, and T. Reuschlé (2021a). "Alteration-Induced Volcano Instability at La Soufrière de Guadeloupe (Eastern Caribbean)". Journal of Geophysical Research: Solid Earth 126(8). DOI: $10.1029 / 2021$ jb022514.

Heap, M. J., T. Baumann, H. A. Gilg, S. Kolzenburg, A. G. Ryan, M. Villeneuve, J. K. Russell, L. A. Kennedy, M. Rosas-Carbajal, and M. A. Clynne (2021b). "Hydrothermal alteration can result in pore pressurization and volcano instability". Geology 49(11), pp. 1348-1352. Dor: 10.1130/g49063.1.

Heap, M. J., D. M. Gravley, B. M. Kennedy, H. A. Gilg, E. Bertolett, and S. L. Barker (2020a). "Quantifying the role of hydrothermal alteration in creating geothermal and epithermal mineral resources: The Ohakuri ignimbrite (Taupō Volcanic Zone, New Zealand)". Journal of Volcanology and Geothermal Research 390, p. 106703. Dor: 10.1016/j . jvolgeores.2019.106703.

Heap, M. J. and B. M. Kennedy (2016). "Exploring the scale-dependent permeability of fractured andesite". Earth and Planetary Science Letters 447, pp. 139-150. Dor: $10.1016 / \mathrm{j}$.epsl.2016.05.004.

Heap, M. J., B. M. Kennedy, J. I. Farquharson, J. Ashworth, K. Mayer, M. Letham-Brake, T. Reuschlé, H. A. Gilg, B. Scheu, Y. Lavallée, P. Siratovich, J. Cole, A. D.
Jolly, P. Baud, and D. B. Dingwell (2017a). "A multidisciplinary approach to quantify the permeability of the Whakaari/White Island volcanic hydrothermal system (Taupo Volcanic Zone, New Zealand)". Journal of Volcanology and Geothermal Research 332, pp. 88-108. DoI: $10.1016 / \mathrm{j}$. jvolgeores. 2016.12. 004.

Heap, M. J., A. R. L. Kushnir, H. A. Gilg, F. B. Wadsworth, T. Reuschlé, and P. Baud (2017b). "Microstructural and petrophysical properties of the Permo-Triassic sandstones (Buntsandstein) from the Soultz-sous-Forêts geothermal site (France)". Geothermal Energy 5(1). DoI: 10.1186/s40517-017๑०85-9.

Heap, M. J., V. R. Troll, A. R. L. Kushnir, H. A. Gilg, A. S. D. Collinson, F. M. Deegan, H. Darmawan, N. Seraphine, J. Neuberg, and T. R. Walter (2019). "Hydrothermal alteration of andesitic lava domes can lead to explosive volcanic behaviour". Nature Communications 10(1). DOI: 10.1038/s41467-019-131028.

Heap, M. J., M. Villeneuve, F. Albino, J. I. Farquharson, E. Brothelande, F. Amelung, J.-L. Got, and P. Baud (2020b). "Towards more realistic values of elastic moduli for volcano modelling". Journal of Volcanology and Geothermal Research 390, p. 106684. Dor: 10. 1016/j . jvolgeores. 2019.106684.

Heap, M. J. and M. E. Violay (2021). "The mechanical behaviour and failure modes of volcanic rocks: a review". Bulletin of Volcanology 83(5). DOI: 10.1007/ s00445-021-01447-2.

Hedenquist, J. W. and R. W. Henley (1985). "Hydrothermal eruptions in the Waiotapu geothermal system, New Zealand; their origin, associated breccias, and relation to precious metal mineralization". Economic Geology 80(6), pp. 1640-1668. DOI: 10 . 2113/gsecongeo.80.6.1640.

Hurwitz, S. (2003). "Groundwater flow, heat transport, and water table position within volcanic edifices: Implications for volcanic processes in the Cascade Range". Journal of Geophysical Research 108(B12). Dor: $10.1029 / 2003$ jb002565.

Kavanagh, J. L., T. Menand, and R. S. J. Sparks (2006). "An experimental investigation of sill formation and propagation in layered elastic media". Earth and Planetary Science Letters 245(3-4), pp. 799-813. DoI: $10.1016 / j$.epsl.2006.03.025.

Kennedy, B., E. Holohan, J. Stix, D. Gravley, J. Davidson, and J. Cole (2018). "Magma plumbing beneath collapse caldera volcanic systems". Earth-Science Reviews 177, pp. 404-424. DoI: 10.1016/j . earscirev . 2017.12.002.

Kennedy, B., A. Jellinek, J. Russell, A. Nichols, and N. Vigouroux (2010). "Time-and temperaturedependent conduit wall porosity: A key control on degassing and explosivity at Tarawera volcano, New Zealand". Earth and Planetary Science Letters 299(12), pp. 126-137. DoI: 10.1016/j .eps1.2010.08.028. 
Kennedy, B. M., A. Farquhar, R. Hilderman, M. C. Villeneuve, M. J. Heap, S. Mordensky, G. Kilgour, A. Jolly, B. Christenson, and T. Reuschlé (2020). "Pressure Controlled Permeability in a Conduit Filled with Fractured Hydrothermal Breccia Reconstructed from Ballistics from Whakaari (White Island), New Zealand". Geosciences 10(4), p. 138. Dor: 10.3390/ geosciences 10040138.

Kennedy, B. M., F. B. Wadsworth, J. Vasseur, C. I. Schipper, A. M. Jellinek, F. W. von Aulock, K.-U. Hess, J. K. Russell, Y. Lavallée, A. R. L. Nichols, and D. B. Dingwell (2016). "Surface tension driven processes densify and retain permeability in magma and lava". Earth and Planetary Science Letters 433, pp. 116-124. DoI: $10.1016 / \mathrm{j}$.epsl.2015.10.031.

Kirov, G., V. Pechigargov, and E. Landzheva (1979). "Experimental crystallization of volcanic glasses in a thermal gradient field". Chemical Geology 26(1-2), pp. 17-28. DoI: 10.1016/0009-2541(79)90027-5.

Kilıç, A. and A. Teymen (2008). "Determination of mechanical properties of rocks using simple methods". Bulletin of Engineering Geology and the Environment 67(2), pp. 237-244. DOI: $10.1007 /$ s 10064-008-01283.

Klinkenberg, L. J. (1941). "The permeability of porous media to liquids and gases". Drilling and production practice. American Petroleum Institute.

Kloprogge, J. T. (1999). "Synthesis of Smectite Clay Minerals: A Critical Review". Clays and Clay Minerals 47(5), pp. 529-554. DoI: 10.1346/ccmn. 1999. 0470501.

Krumbholz, M., C. F. Hieronymus, S. Burchardt, V. R. Troll, D. C. Tanner, and N. Friese (2014). "Weibulldistributed dyke thickness reflects probabilistic character of host-rock strength". Nature Communications 5(1). DOI: $10.1038 /$ ncomms 4272.

Kushnir, A. R. L., M. J. Heap, P. Baud, H. A. Gilg, T. Reuschlé, C. Lerouge, C. Dezayes, and P. Duringer (2018). "Characterizing the physical properties of rocks from the Paleozoic to Permo-Triassic transition in the Upper Rhine Graben". Geothermal Energy 6(1). DoI: $10.1186 / \mathrm{s} 40517-018-0103-6$.

Lamur, A., Y. Lavallée, F. E. Iddon, A. J. Hornby, J. E. Kendrick, F. W. von Aulock, and F. B. Wadsworth (2018). "Disclosing the temperature of columnar jointing in lavas". Nature Communications 9(1). DoI: $10.1038 / \mathrm{s} 41467-018-03842-4$.

Leonard, G., J. Cole, I. Nairn, and S. Self (2002). "Basalt triggering of the c. AD 1305 Kaharoa rhyolite eruption, Tarawera Volcanic Complex, New Zealand". Journal of Volcanology and Geothermal Research 115(34), pp. 461-486. Dor: 10.1016/s0377-0273(01)003262.

Maccaferri, F., M. Bonafede, and E. Rivalta (2011). “A quantitative study of the mechanisms governing dike propagation, dike arrest and sill formation". Journal of Volcanology and Geothermal Research 208(1-2), pp. 39-50. DoI: 10.1016/j . jvolgeores. 2011.09.001.
Magee, C. and C. A.-L. Jackson (2020). "Seismic reflection data reveal the 3D structure of the newly discovered Exmouth Dyke Swarm, offshore NW Australia". Solid Earth 11(2), pp. 579-606. Dor: 10.5194/se-11579-2020.

Mayer, K., B. Scheu, H. A. Gilg, M. J. Heap, B. M. Kennedy, Y. Lavallée, M. Letham-Brake, and D. B. Dingwell (2015). "Experimental constraints on phreatic eruption processes at Whakaari (White Island volcano)". Journal of Volcanology and Geothermal Research 302, pp. 150-162. DoI: $10.1016 / j$. jvolgeores.2015.06.014.

McNamara, D. D., S. Sewell, E. Buscarlet, and I. C. Wallis (2016). "A review of the Rotokawa Geothermal Field, New Zealand". Geothermics 59, pp. 281-293. Dor: $10.1016 /$ j.geothermics.2015.07.007.

Montanaro, C., S. J. Cronin, B. Scheu, B. Kennedy, and B. Scott (2020). "Complex crater fields formed by steam-driven eruptions: Lake Okaro, New Zealand”. GSA Bulletin 132(9-10), pp. 1914-1930. DoI: 10 . 1130/b35276.1.

Montanaro, C., S. J. Cronin, B. Scheu, B. Kennedy, B. J. Scott, and D. B. Dingwell (2021). "Host Rock Variability Powers the Diversity of Steam-Driven Eruptions". Geophysical Research Letters 48(1). DOI: 10 . 1029/2020gl089025.

Moon, V., J. Bradshaw, R. Smith, and W. de Lange (2005). "Geotechnical characterisation of stratocone crater wall sequences, White Island Volcano, New Zealand". Engineering Geology 81(2), pp. 146-178. Dor: $10.1016 / \mathrm{j}$.enggeo.2005.07.014.

Mordensky, S. P., M. C. Villeneuve, J. I. Farquharson, B. M. Kennedy, M. J. Heap, and D. M. Gravley (2018a). "Rock mass properties and edifice strength data from Pinnacle Ridge, Mt. Ruapehu, New Zealand". Journal of Volcanology and Geothermal Research 367, pp. 46-62. DoI: 10.1016/j . jvolgeores . 2018.09.012.

Mordensky, S. P., M. C. Villeneuve, B. M. Kennedy, M. J. Heap, D. M. Gravley, J. I. Farquharson, and T. Reuschlé (2018b). "Physical and mechanical property relationships of a shallow intrusion and volcanic host rock, Pinnacle Ridge, Mt. Ruapehu, New Zealand". Journal of Volcanology and Geothermal Research 359, pp. 1-20. DoI: $10.1016 / j$. jvolgeores . 2018.05.020.

Nadeau, O., J. Stix, and A. E. Williams-Jones (2015). "Links between arc volcanoes and porphyryepithermal ore deposits". Geology 44(1), pp. 11-14. DOI: $10.1130 / \mathrm{g} 37262.1$.

Óskarsson, B. V. and M. S. Riishuus (2013). "The mode of emplacement of Neogene flood basalts in Eastern Iceland: Facies architecture and structure of the Hólmar and Grjótá olivine basalt groups". Journal of Volcanology and Geothermal Research 267, pp. 92-118. DoI: $10.1016 / \mathrm{j}$. jvolgeores . 2013.09.010.

Panta, R. K. (2015). "Toward human MARS scanning: improving spectral performance for soft tissue imaging". PhD thesis. University of Otago, New Zealand. 
Pola, A., G. Crosta, N. Fusi, V. Barberini, and G. Norini (2012). "Influence of alteration on physical properties of volcanic rocks". Tectonophysics 566-567, pp. 67-86. Dor: $10.1016 / \mathrm{j}$. tecto. 2012.07.017.

Putirka, K. D. (2008). "Thermometers and Barometers for Volcanic Systems". Reviews in Mineralogy and Geochemistry 69(1), pp. 61-120. DOI: 10.2138/rmg.2008. 69.3.

Quane, S. L., J. K. Russell, and E. A. Friedlander (2009). "Time scales of compaction in volcanic systems". Geology 37(5), pp. 471-474. Dor: 10.1130/g25625a.1.

Quinao, J., L. Sirad-Azwar, J. Clearwater, V. Hoepfinger, M. Le Brun, and C. Bardsley (2013). "Analyses and modeling of reservoir pressure changes to interpret the Rotokawa Geothermal Field response to Nga Awa Purua Power Station operation". Proceedings of the 38th workshop on geothermal reservoir engineering. Stanford University, Stanford, California. Vol. 1113.

Rateau, R., N. Schofield, and M. Smith (2013). "The potential role of igneous intrusions on hydrocarbon migration, West of Shetland". Petroleum Geoscience 19(3), pp. 259-272. DoI: 10.1144/petgeo2012-035.

Rissmann, C., A. Nicol, J. Cole, B. Kennedy, J. Fairley, B. Christenson, M. Leybourne, S. Milicich, U. Ring, and D. Gravley (2011). "Fluid flow associated with silicic lava domes and faults, Ohaaki hydrothermal field, New Zealand". Journal of Volcanology and Geothermal Research 204(1-4), pp. 12-26. DoI: $10.1016 / \mathrm{j}$. jvolgeores.2011.05.002.

Rowland, J. V. and S. F. Simmons (2012). "Hydrologic, Magmatic, and Tectonic Controls on Hydrothermal Flow, Taupo Volcanic Zone, New Zealand: Implications for the Formation of Epithermal Vein Deposits". Economic Geology 107(3), pp. 427-457. Dor: 10.2113/econgeo. 107.3.427.

Saar, M. O. and M. Manga (1999). "Permeabilityporosity relationship in vesicular basalts". Geophysical Research Letters 26(1), pp. 111-114. Dor: 10.1029/ $1998 \mathrm{gl} 900256$.

Saubin, E., B. Kennedy, H. Tuffen, M. Villeneuve, J. Davidson, and S. Burchardt (2019). "Comparative field study of shallow rhyolite intrusions in Iceland: Emplacement mechanisms and impact on country rocks". Journal of Volcanology and Geothermal Research 388 , p. 106691 . DoI: $10.1016 / \mathrm{j}$. jvolgeores . 2019 . 106691.

Schauroth, J., F. B. Wadsworth, B. Kennedy, F. W. von Aulock, Y. Lavallée, D. E. Damby, J. Vasseur, B. Scheu, and D. B. Dingwell (2016). "Conduit margin heating and deformation during the AD 1886 basaltic Plinian eruption at Tarawera volcano, New Zealand". Bulletin of Volcanology 78(2). DOI: 10.1007/s00445016-1006-7.

Senger, K., J. Millett, S. Planke, K. Ogata, C. H. Eide, M. Festøy, O. Galland, and D. A. Jerram (2017). "Effects of igneous intrusions on the petroleum system: a review". First Break 35(6). DoI: $10.3997 / 1365$ 2397.2017011.
Senger, K., S. Roy, A. Braathen, S. J. Buckley, K. Bælum, L. Gernigon, R. Mjelde, R. Noormets, K. Ogata, S. Olaussen, S. Planke, B. O. Ruud, and J. Tveranger (2013). "Geometries of doleritic intrusions in central Spitsbergen, Svalbard: an integrated study of an onshore-offshore magmatic province with implications for $\mathrm{CO}_{2}$ sequestration". Norwegian Journal of Geology 93, pp. 143-166.

Spacapan, J., A. D’Odorico, O. Palma, O. Galland, E. R. Vera, R. Ruiz, H. Leanza, A. Medialdea, and R. Manceda (2020). "Igneous petroleum systems in the Malargüe fold and thrust belt, R1o Grande Valley area, Neuquén Basin, Argentina". Marine and Petroleum Geology 111, pp. 309-331. Dor: 10.1016/ j.marpetgeo.2019.08.038.

Spittler, N., B. Davidsdottir, E. Shafiei, J. Leaver, E. I. Asgeirsson, and H. Stefansson (2020). "The role of geothermal resources in sustainable power system planning in Iceland". Renewable Energy 153, pp. 1081-1090. DoI: 10.1016/j . renene. 2020.02.046. Sruoga, P., N. Rubinstein, and G. Hinterwimmer (2004). "Porosity and permeability in volcanic rocks: a case study on the Serie Tobífera, South Patagonia, Argentina". Journal of Volcanology and Geothermal Research 132(1), pp. 31-43. DOI: 10.1016 / s0377 $0273(03) 00419-0$.

Stix, J., B. Kennedy, M. Hannington, H. Gibson, R. Fiske, W. Mueller, and J. Franklin (2003). "Calderaforming processes and the origin of submarine volcanogenic massive sulfide deposits". Geology 31(4), p. 375. DOI: $10.1130 / 0091-7613(2003) 031<0375$ : cfpato>2.0.co;2.

Taisne, B. and C. Jaupart (2009). "Dike propagation through layered rocks". Journal of Geophysical Research 114(B9). DoI: 10.1029/2008jb006228.

Taisne, B., S. Tait, and C. Jaupart (2011). "Conditions for the arrest of a vertical propagating dyke". Bulletin of Volcanology 73(2), pp. 191-204. Dor: 10.1007/ s00445-010-0440-1.

Torabi, S. R., M. Ataei, and M. Javanshir (2010). "Application of Schmidt rebound number for estimating rock strength under specific geological conditions". Journal of Mining and Environment 1(2). DOI: 10 . 22044/jme.2011.9.

Troll, V. R. (2002). "Magma Mixing and Crustal Recycling Recorded in Ternary Feldspar from Compositionally Zoned Peralkaline Ignimbrite A', Gran Canaria, Canary Islands". Journal of Petrology 43(2), pp. 243-270. DoI: 10.1093/petrology/43.2.243.

Vasseur, J. and F. B. Wadsworth (2019). "The Permeability of Columnar Jointed Lava". Journal of Geophysical Research: Solid Earth 124(11), pp. 11305-11315. Dor: 10.1029/2019jb018118.

Vasseur, J., F. B. Wadsworth, Y. Lavallée, K.-U. Hess, and D. B. Dingwell (2013). "Volcanic sintering: Timescales of viscous densification and strength recovery". Geophysical Research Letters 40(21), pp. 5658-5664. DOI: $10.1002 / 2013 \mathrm{gl} 1058105$. 
von Aulock, F. W., A. R. L. Nichols, B. M. Kennedy, and C. Oze (2013). "Timescales of texture development in a cooling lava dome". Geochimica et Cosmochimica Acta 114, pp. 72-80. DoI: $10.1016 /$ j . gca. 2013.03. 012.

Wadsworth, F. B., J. Vasseur, E. W. Llewellin, R. J. Brown, H. Tuffen, J. E. Gardner, J. E. Kendrick, Y. Lavallée, K. J. Dobson, M. J. Heap, D. B. Dingwell, K.-U. Hess, J. Schauroth, F. W. von Aulock, A. R. L. Kushnir, and F. Marone (2021). "A model for permeability evolution during volcanic welding". Journal of Volcanology and Geothermal Research 409, p. 107118. Dor: 10.1016/j. jvolgeores.2020.107118.

Wadsworth, F. B., J. Vasseur, J. Schauroth, E. W. Llewellin, K. J. Dobson, T. Havard, B. Scheu, F. W. von Aulock, J. E. Gardner, D. B. Dingwell, K.-U. Hess, M. Colombier, F. Marone, H. Tuffen, and M. J. Heap (2019). "A general model for welding of ash particles in volcanic systems validated using in situ X-ray tomography". Earth and Planetary Science Letters 525, p. 115726. DOI: 10.1016/j.eps1.2019.115726.
Walker, G. P. L. (1960). "Zeolite Zones and Dike Distribution in Relation to the Structure of the Basalts of Eastern Iceland". The Journal of Geology 68(5), pp. 515-528. Dor: 10.1086/626685.

Walker, G. P. (1983). "Ignimbrite types and ignimbrite problems". Journal of Volcanology and Geothermal Research 17(1-4), pp. 65-88. DoI: 10 . 1016/03770273(83) 90062-8.

Watson, A., J. Psutka, T. Stewart, and D. Moore (2007). "Investigations and monitoring of rock slopes at Checkerboard Creek and Little Chief Slide". 1st Canada-US Rock Mechanics Symposium. OnePetro.

Wolff, J. and J. Wright (1981). "Rheomorphism of welded tuffs". Journal of Volcanology and Geothermal Research 10(1-3), pp. 13-34. DOI: $10.1016 / 0377-$ 0273(81) 90052-4.

Wyering, L., M. Villeneuve, I. Wallis, P. Siratovich, B. Kennedy, D. Gravley, and J. Cant (2014). "Mechanical and physical properties of hydrothermally altered rocks, Taupo Volcanic Zone, New Zealand". Journal of Volcanology and Geothermal Research 288, pp. 7693. DoI: 10.1016/j. jvolgeores. 2014.10.008. 